\title{
A review of MIS 5e sea-level proxies around Japan
}

\author{
Evan Tam ${ }^{1,2}$ and Yusuke Yokoyama ${ }^{1,2,3,4,5}$ \\ ${ }^{1}$ Atmosphere and Ocean Research Institute, The University of Tokyo, 5-1-5 Kashiwanoha, \\ Kashiwa, 277-8564, Japan \\ ${ }^{2}$ Graduate Program on Environmental Sciences, Graduate School of Arts and Sciences, The University of \\ Tokyo, 3-8-1 Komaba, Meguro-ku, Tokyo, 153-8902, Japan \\ ${ }^{3}$ Department of Earth and Planetary Science, Graduate School of Science, The University of Tokyo, \\ 7-3-1 Hongo, Bunkyo-ku, Tokyo, 113-0033, Japan \\ ${ }^{4}$ Biogeochemistry Program, Japan Agency for Marine-Earth Science and Technology, 2-15 Natsushima-cho, \\ Yokosuka-city, Kanagawa, 237-0061, Japan \\ ${ }^{5}$ Research School of Physics, The Australian National University, Canberra, ACT 2601, Australia
}

Correspondence: Evan Tam (evan.tam@g.ecc.u-tokyo.ac.jp)

Received: 29 November 2020 - Discussion started: 14 December 2020

Revised: 13 February 2021 - Accepted: 19 February 2021 - Published: 6 April 2021

\begin{abstract}
Sea-level proxies for Marine Isotopic Stage 5e (MIS 5e, ca. $124 \mathrm{ka}$ ) are abundant along the Japanese shoreline and have been documented for over at least the past 60 years. The bulk of these sea-level proxies are identified in Japan as marine terraces, often correlated by stratigraphic relationships to identified tephra layers, or other chronologically interpreted strata. Use of stratigraphic correlation in conjunction with other techniques such as paleontological analysis, tectonic uplift rates, tephra (volcanic ash), uranium-thorium (U$\mathrm{Th}$ ), and carbon-14 $\left({ }^{14} \mathrm{C}\right)$ dating have connected Japan's landforms to global patterns of sea-level change. This paper reviews over 60 years of publications containing sea-level proxies correlated with MIS 5e in Japan. Data collected for this review have been added to the World Atlas of Last Interglacial Shorelines (WALIS), following their standardizations on the elements necessary to analyze paleosea-levels. This paper reviewed over 70 studies, assembling data points for over 300 locations and examining related papers denoting sealevel indicators for MIS 5e. The database compiled for this review (Tam and Yokoyama, 2020) is available at https://doi.org/10.5281/zenodo.4294326. Sea-level proxy studies in Japan rely heavily on chronostratigraphic techniques and are recognized as reliable, though opportunities exist for further constraining through the further use of numerical age dating techniques.
\end{abstract}

1

\section{Introduction}

Marine Isotope Stage (MIS) 5e is of particular interest because of its position as the last major interglacial period before present, and due to similarities in global mean temperatures during this period to projected changes in climate, observations of MIS 5e could aid in quantifying sea-level change in the current and coming century (Stirling et al., 1995; Rohling et al., 2008; Rahmstorf, 2007; Church et al., 2001). This stage has been constrained to between 128$116 \mathrm{ka}$ (Stirling et al., 1998; Yokoyama and Esat, 2011), with average sea-level rise in tectonically stable areas at $5-9 \mathrm{~m}$ higher than at present (Dutton and Lambeck, 2012). Sealevel increases are credited to warmer global temperatures, an increased influx of icebergs into the ocean, or varying degrees of both (Overpeck et al., 2006; Otto-Bliesner et al., 2006; Yokoyama and Esat, 2011). Accurate measurements of changes in ocean basin seawater volume and ice sheet volume are necessary to parameterize the effects of tectonics, isostasy, and eustasy on fluxes in sea-level for a given location (Milne, 2014; Yokoyama et al., 2018, 2019a). These data are vital for accurate glacial isostatic adjustment (GIA) modeling and calculation of tectonic uplift rates using coastal sea-level proxies (Okuno et al., 2014; Fukuyo et al., 2020). 


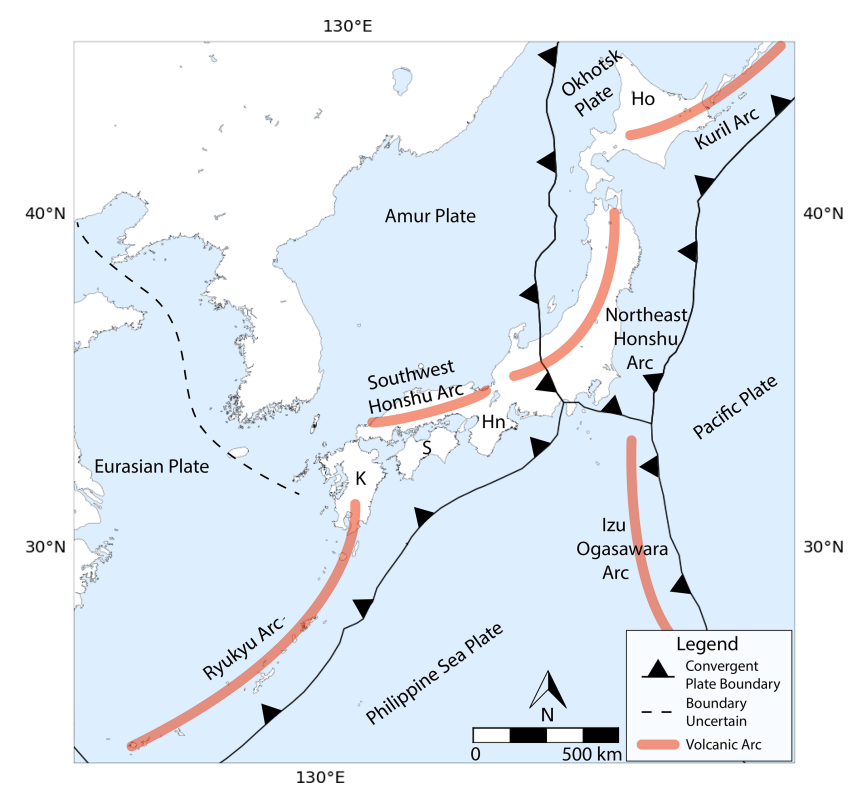

Figure 1. Modified from Taira (2001). An overview of the tectonic plates that compose and surround the Japanese archipelago, detailing the interactions between the Okhotsk, Amura, Eurasian, Pacific, and Philippine sea plates; their plate boundaries; and the resulting volcanic arcs. Names of the major islands of Japan are abbreviated: Ho: Hokkaido; Hn: Honshu; S: Shikoku; K: Kyushu.

This paper serves as context to the data collected on MIS 5e sea-level proxies in and around Japan. The database was compiled as a part of the World Atlas of Last Interglacial Shorelines (WALIS), which aims to globally compile MIS 5e sea-level indicators in a standardized format (https://warmcoasts.eu/world-atlas.html, last access: 31 January 2021). Descriptions of each database field can be found here: https://doi.org/10.5281/zenodo.3961543 (Rovere et al., 2020), compiled at the following website: https: //walis-help.readthedocs.io/en/latest/ (last access: 31 January 2021). The regional database for sea-level indicators of Japan during this period can be found at the following link: https://doi.org/10.5281/zenodo.4294326 (Tam and Yokoyama, 2020). This database reviewed over 70 studies, extracting 315 representative sea-level indicators across Japan. Among these, 310 proxies were age constrained by stratigraphic correlation, 149 utilized tephra-stratigraphic correlation, 6 used optically stimulated luminescence (OSL) dating, and 5 employed U-Th dating, with studies frequently using multiple techniques.

\section{Literature overview}

\subsection{Geologic background}

The Japanese archipelago is tectonically one of the most active locations in the world (Ando et al., 2018; Nakanishi et al., 2020; Yokoyama et al., 2016), consisting of several island arcs created by the collision of at least five plates: the Amurian, Eurasian, Okhotsk, Pacific, and Philippine sea plates (Fig. 1). The archipelago is primarily composed of four large islands: Hokkaido, Honshu, Shikoku, and Kyushu. Subduction of the Pacific plate beneath the Okhotsk plate and the Philippine sea plate, forms the Kuril and Izu-Ogasawara arcs and the northeast Honshu arc. Additionally, subduction of the Philippine sea plate beneath the Okhotsk and Amurian plates forms the southwest Honshu arc, and subduction beneath the Eurasian plate forms the Ryukyu arc (Taira, 2001; Taira et al., 2016; Apel et al., 2006). This unique convergence of plates results in distinct uplift and subsidence patterns that alter marine terrace elevations (Ota and Omura, 1991), with MIS 5e creating sea-level indicators at elevations ranging from -85.5 to $205 \mathrm{~m}$. Japan is also host to a large number of active volcanoes due to its tectonic activity, and records of volcanic activity are vital in constraining ages of terraces and sea-level proxies (as discussed later).

Almost all studies of sea-level proxies defining sea-level maxima during MIS 5e in Japan utilize analyses of marine terraces. Relatively high uplift rates are found in many coastal regions in Japan, preserving sea-level highstands as staircase terraces. Terraces have been previously subcategorized into three types: topographically defined marine terraces, sedimentologically defined marine terraces, and terraces defined by paleontological evidence (Ota and Omura, 1991), though many studies provide little information on marine terrace details. Sea-level proxies in this study are categorized according to definitions provided in Rovere et al. (2016; Table 1).

\subsection{Historical studies and U-Th dating}

Earlier studies chronicling sea-level proxies in Japan generally utilized paleontological evidence to constrain marine deposit ages (Kamada and Niino, 1955; Sakaguchi, 1959; Yonekura, 1968), or they used proxies to calculate Quaternary crustal movement (e.g., Yoshikawa et al., 1964; Ota, 1971). Marine terraces were correlated to the Riss-Würm interglacial period (then identified between 90-100 ka) but have since been reassessed to align with MIS 5e sea-level highstands. Paleontological proxies such as Mollusca species were utilized to identify warmer climate conditions associated with the deposition of sea-level highstand marine sediments (e.g., Yonekura, 1968).

In the 1970s, the utilization of uranium-thorium (U-Th, a.k.a. U-series) dating provided age constraints on fossilized coral terraces representing sea-level highstands globally. Since then, studies examining Kikai Island and other Ryukyu Islands combined with results from Barbados (Thompson et al., 2011; James et al., 1971) and Papua New Guinea (Chappell, 1974; Chappell et al., 1996; Yokoyama et al., 2001a, b) have reconfirmed constrained dates of terraces representing sea-level highstands, matching age groups of approximately 120, 100, 80, and $60 \mathrm{ka}$ (Konishi et al., 1974; Yonekura et al., 
Table 1. Varieties of sea-level proxies identified in this study.

\begin{tabular}{|c|c|c|c|}
\hline $\begin{array}{l}\text { Sea-level proxy } \\
\text { type }\end{array}$ & $\begin{array}{l}\text { Proxy description } \\
\text { (from Rovere et al., 2016) }\end{array}$ & Description of RWL calculation & Description of IR calculation \\
\hline Marine terrace & $\begin{array}{l}\text { Relatively flat surfaces of marine ori- } \\
\text { gin, shaped by marine erosion or accu- } \\
\text { mulation of sediments from erosional } \\
\text { and depositional processes (Pirazzoli, } \\
\text { 2005) }\end{array}$ & $\begin{array}{l}\text { Tidal prediction heights, aver- } \\
\text { aged over daily and then } 3 \text { - } \\
\text { month time spans, then corre- } \\
\text { lated regionally (see Sect. } 3 \text { ) }\end{array}$ & $\begin{array}{l}\text { Range of tidal prediction heights, } \\
\text { calculated over a daily period and } \\
\text { then averaged over a 3-month time } \\
\text { span, then correlated regionally (see } \\
\text { Sect. 3) }\end{array}$ \\
\hline Beach deposits & $\begin{array}{l}\text { Accumulation of loose sediments found } \\
\text { on coastal surfaces, such as sand, } \\
\text { gravel, or pebbles (Anthony, 2005) }\end{array}$ & See above & See above \\
\hline Coral terrace & $\begin{array}{l}\text { A marine terrace formed specifically } \\
\text { from the interaction between biocon- } \\
\text { structional (coral reef growth) and ero- } \\
\text { sional processes (Anthony, 2008) }\end{array}$ & MLLW - $\left(\mathrm{MD}_{\mathrm{p}} / 2\right)$ & $\mathrm{MD}_{\mathrm{p}}$ - see Table 3 \\
\hline
\end{tabular}

2001). Ages from oxygen isotope analyses of deep-sea sediment cores also corresponded to these high-sea-level periods, linking these analyses together and more accurately defining MIS 5e, 5c, and 5a (Lisiecki and Raymo, 2005; Yokoyama et al., 2019a; Ota, 1986). Though U-Th dating continues to be used in Japan (e.g., Inagaki and Omura, 2006), suitable samples of carbonate origin are generally found only in the Ryukyu Islands (Ota and Omura, 1991).

\subsection{Chronostratigraphy and tephrochronology}

Studies examining sea-level proxies in Japan heavily rely on chronostratigraphic correlations, employing key widespread tephra and stratigraphic layers, the latter of which are often constrained by the former. Machida (1975) used tephrochronology with fission track ages to correlate highsea-level stages as observed in Papua New Guinea and Barbados (Ota and Omura, 1991; Chappell, 1974; Chappell et al., 1996; Yokoyama et al., 2001a, b), paving the way for the use of tephra and pumice layers as a common chronohorizon dating technique in stratigraphic analysis. Characterization of glass mineral assemblages and chemical composition through electron microprobe, instrumental neutron activation analysis, and inductively coupled plasma mass spectrometry has allowed for identification of chemical signatures of specific tephra layers, linking these layers to specific eruptive events and volcanoes (Machida, 2002). Thus, it became possible to link widely distributed tephra layers and associated stratigraphic layers/marine terraces by age and to Marine Isotope Stages (Machida and Arai, 2003). Key tephra layers from individual eruptions have broad distributions, with Japanese-sourced tephra layers identified in Korea and the Ryukyu Islands (Fig. 2; Machida, 2002).

Dating of tephra layers is essential in constraining ages of stratigraphic layers, and ${ }^{14} \mathrm{C}$, fission-track, U-Th, ther-

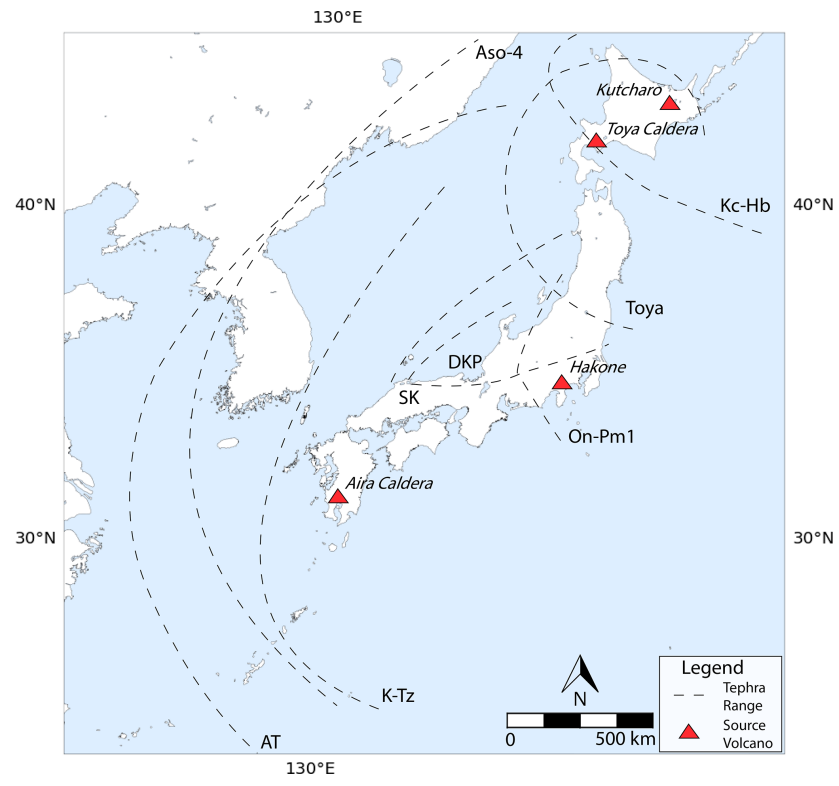

Figure 2. Tephra distribution map in and around Japan, modified from Machida (2002). Tephra recognized as key chronohorizons in this study include Toya, Kc-Hb, On-Pm1, Aso-4, K-Tz, SK, DKP, and AT. Source volcanoes are indicated by red triangles.

moluminescence, electron spin resonance, and $\mathrm{K}-\mathrm{Ar}$ dating techniques have all been utilized to establish and crosscheck ages associated with tephra depositional events. Due to the wide distribution of tephra layers and the plethora of dating techniques available for analyzing them, chronostratigraphic correlation to identified tephra layers or ageconstrained stratigraphic layers is considered reliable and heavily used in Japan (Machida, 2002; see Table 4).

Of the many tephra layers identified and employed as reliable chronostratigraphic horizons, the Toya tephra, Zarame 
pumice (ZP), Aso-4, and Aira-Tn (AT) layers have broad distributions and are commonly used to constrain ages of sea-level proxies around Japan (Fig. 2). The Toya tephra is widely distributed over much of Hokkaido and northern Honshu, sourced from eruptions that formed the Toya Caldera (Machida et al., 1987). Ages have been constrained to between $112-115 \mathrm{ka}$ by stratigraphic correlations of tephras and terrace heights (Machida, 2002), though zircon U-Th$\mathrm{Pb}$ dating and aliquot regeneration-red thermal luminescence dating have given ages of $108 \pm 19 \mathrm{ka}$ and $104 \pm 30$ $118 \pm 30 \mathrm{ka}$ (Ito, 2014; Ganzawa and Ike, 2011). The ZP layer was deposited as thick airlaid tephra from an unknown volcano and is found below the Toya tephra and above MIS 5 e surfaces in stratigraphic sequences, with ages estimated by Miyauchi (1985) between 110-120 ka (Matsuura et al., 2019; Miyauchi, 1985). The ZP layer has been identified in studies examining northern Honshu, though mainly in the well-studied Kamikita coastal region where Middle and Late Pleistocene terraces are widely distributed on multiple levels (e.g., Matsuura et al., 2019).

The AT tephra is one of the most widespread tephra in Japan, with traces having been found in Kyushu, Shikoku, Honshu, and Korea (Machida and Arai, 2003, 1983; Machida, 2002). The tephra was sourced from three phases of eruptions of the Aira caldera in northern Kagoshima Bay and has been dated by ${ }^{14} \mathrm{C}$ to an age of $25.12 \pm 0.27 \mathrm{ka} \mathrm{BP}$ (Miyairi et al., 2004; Machida and Arai, 2003). The Aso4 tephra layer represents the youngest and largest tephra layer from the Aso Caldera in central Kyushu and was distributed as far as eastern Hokkaido, making it ideal for terrace chronology (Machida, 2002; Aoki, 2008). Ages between $86.8-87.3 \mathrm{ka}$ were obtained from detailed $\delta^{18} \mathrm{O}$ isotopic stratigraphy from ocean cores collected in the northwest Pacific Ocean and the Sea of Okhotsk (Aoki, 2008).

Though techniques defining tephra ages have become more precise over time, overreliance on tephra-based chronostratigraphy can be precarious, as certain tephra layers have been and still are described with large age uncertainties. Although the Toya tephra has since been more accurately constrained (Ito, 2014; Ganzawa and Ike, 2011), historical utilizations of ages from the original fission track age, along with ages from stratigraphic constraints of the ash layer in the northern part of Japan, resulted in a range of 90-130 ka (Okumura and Sagawa, 1984; Miyauchi, 1988; Ota and Omura, 1991). An applied example, updated ages of tephra-defined marine terraces from Tanegashima (Machida et al., 2001) compared with the original age interpretation (Ota and Machida, 1987) show a discrepancy of $20 \mathrm{kyr}$. Large uncertainty ranges from various dating techniques combined with tephra layer ages defined solely by stratigraphic correlation alone indicate that while tephrostratigraphy is viable, direct dating of tephra layers and sea-level proxies should be utilized when available. It should also be noted that age correlation of sea-level proxies in the absence of tephra layers is not uncommon when deemed equivalent to well-constrained proxies within the region (e.g., Koike and Machida, 2001).

\subsection{Tectonic uplift studies}

The reliance on tephrochronology-based chronostratigraphy and chronostratigraphic correlation without use of a direct dating technique highlights the frequent lack of directly datable samples associated with sea-level proxies in Japan. Marine terraces, when found without reliable tephra layers, have been correlated by counting interglacial deposits/terraces backwards from MIS 5e (Ito et al., 2017), or by comparing relationships within a series of terraces where one terrace is constrained by recognized tephra layers, ${ }^{14} \mathrm{C}$ dating (for younger terraces in the series), or paleontological proxies such as molluscs (Koike and Machida, 2001). Due to the relationship between uplift and terrace preservation, regional uplift rates have been utilized to assign MIS stages to terrace sequences, and likewise terrace ages have been used to calculate uplift rates.

Often, studies that identify sea-level proxies in Japan focus on calculating regional tectonic uplift rates and patterns (e.g., Suzuki et al., 2011; Miyazaki and Ishimura, 2018). As uplift rate calculations require dating of an uplifted proxy, MIS 5e terraces can be utilized for their defined age range. When possible, numerical age dating techniques (see below for more techniques) or tephrochronology are utilized to constrain ages to calculate the regional uplift rates (e.g., Hiroki, 1994; Ota and Odagiri, 1994). If direct dating techniques cannot be employed, stratigraphic correlation has been relied on to constrain terrace ages. Terrace heights, regional uplift rates, and sediments signifying transitions between sea-level highstands have been used to designate MIS 5e terraces when there is a lack of datable material (Yoshikawa et al., 1964). River profiles have also been used to designate sea-level/marine terrace height relationships (Yoshiyama, 1990) and implied regional stratigraphic relationships (Koike and Machida, 2001). However, these techniques introduce a higher possibility of dating uncertainties due to the use of stratigraphic relationships (as mentioned earlier) and age calculation based on regional uplift rates, which rely on the assumption of constant uplift over the proxy's history.

\subsection{Other techniques}

While the abovementioned geochronological techniques represent the bulk of techniques commonly utilized in sea-level proxy identification, many others have been employed in assessing their ages. In addition to U-Th dating, tephrochronology, and stratigraphic correlation, a limited number of investigative studies utilizing OSL dating have been performed on marine terraces in Japan. Samples from the Noto Peninsula, the Kamikita coast, and the Oga Peninsula have been analyzed utilizing thermoluminescence and multiple-aliquot 
Table 2. Elevation measurement techniques identified in this study.

\begin{tabular}{lll}
\hline Measurement technique & Description (from Rovere et al., 2016) & $\begin{array}{l}\text { Typical vertical error under optimal } \\
\text { conditions }\end{array}$ \\
\hline Barometric altimeter & $\begin{array}{l}\text { Difference in barometric pressure between a point of } \\
\text { known elevation (often sea level) and a point of un- } \\
\text { known elevation }\end{array}$ & Up to $\pm 20 \%$ of elevation measurement \\
\hline Differential GPS & $\begin{array}{l}\text { GPS positions acquired in the field and corrected in real } \\
\text { time or during post-processing }\end{array}$ & $\begin{array}{l} \pm 0.02 / \pm 0.08 \mathrm{~m}, \text { depending on survey } \\
\text { conditions and instruments used }\end{array}$ \\
\hline Metered tape or rod & $\begin{array}{l}\text { The end of a tape or rod is placed at a known elevation } \\
\text { point, and the elevation of the unknown point is calcu- } \\
\text { lated using the metered tape or rod }\end{array}$ & Up to $\pm 10 \%$ of elevation measurement \\
\hline Not reported & $\begin{array}{l}\text { The elevation measurement technique was not reported, } \\
\text { most probably hand level or metered tape }\end{array}$ & $20 \%$ of the original elevation reported \\
\hline $\begin{array}{l}\text { Topographic map and digi- } \\
\text { tal elevation models }\end{array}$ & $\begin{array}{l}\text { Elevation derived from the contour lines on topographic } \\
\text { maps. Most often used for large-scale landforms (i.e., } \\
\text { marine terraces) }\end{array}$ & $\begin{array}{l}\text { Variable with scale of map and tech- } \\
\text { nique used to derive DEM }\end{array}$ \\
\hline $\begin{array}{l}\text { Total station or auto or hand } \\
\text { level }\end{array}$ & $\begin{array}{l}\text { Total stations or levels measure slope distances from the } \\
\text { instrument to a particular point and triangulate relative } \\
\text { to the } X Y Z \text { coordinates of the base station }\end{array}$ & $\begin{array}{l} \pm 0.1 / \pm 0.2 \mathrm{~m} \text { for total stations, } \\
\pm 0.4 \mathrm{~m} \text { for auto or hand level }\end{array}$ \\
\hline
\end{tabular}

additive dose (MAAD) quartz OSL dating (Tanaka et al., 1997), K-feldspar post-infrared infrared (pIRIR) stimulated luminescence dating (Ito et al., 2017), and both quartz OSL and $\mathrm{K}$-feldspar pIRIR dating (Thiel et al., 2015). Results from Thiel et al. (2015) and Ito et al. (2017) suggest that $\mathrm{K}$-feldspar pIRIR dating is appropriate for dating marine terraces and marine sediments formed during MIS 5 and older, even in locations where quartz OSL is deemed unsuitable. Limited studies have utilized cosmogenic nuclide dating $\left({ }^{10} \mathrm{Be}\right.$ and $\left.{ }^{26} \mathrm{Al}\right)$ to analyze MIS 5e- and MIS 7-associated terraces in the Kii Peninsula and Shikoku (Yokoyama et al., 2015, 2019b). Amino acid racemization has seen limited use in constraining MIS 5e terrace ages in Japan (e.g., Ota and Odagiri, 1994), as has electron spin resonance (ESR) dating (e.g., Ikeya and Ohmura, 1983).

\section{Database details}

As a part of this review, over 70 papers, including three databases and the references therewithin, were examined. Direct latitude and longitude values were provided only in limited studies (specifically in databases provided in Pedoja et al., 2011, 2014), so locations were estimated by comparing mapped locations provided in published studies to Google Earth, or finding an appropriate average location for areas examined in the study. Due to the large quantities of data examined (in Koike and Machida, 2001, alone over 2000 data points), this review aims to broadly represent studies conducted throughout Japan.

\subsection{Data collection and calculations}

Sea-level proxy elevations and uplift rates were recorded from data sources when values were clearly articulated in reviewed studies or could be interpreted from figures. Data retrieved from Koike and Machida (2001) were averaged for each given location. Elevation and uplift rate values describing a single location were summed and divided by the total number of utilized values for the average elevation and uplift rate and noted within our database as averaged. Data from other studies were added to the database to be representative of each region.

Few examined studies listed sea-level proxy elevation margin of error $(\mathrm{MoE})$ values, so values were assigned based on the measurement technique utilized as described in Rovere et al. (2016, Table 2). For proxies that had elevations averaged from multiple points, half of the range between the highest and lowest proxy elevations was added to the MoE. Sea-level proxies with large ranges in elevation resulted in rather large MoEs, which are denoted in the relative sea level (RSL) quality rating as less reliable (see Sect. 5.1).

Tidal ranges were calculated for the Japanese coastline to calculate indicative range (IR), relative water level (RWL), and the upper and lower limits (UL, LL; as defined in Rovere et al., 2016) for modern analogs of sea-level proxies. Tidal predictions were provided by the Hydrographic and Oceanographic Department of the Japan Coast Guard (2020). Tidal predictions for all functional tide gauges were examined for dates between 1 January and 31 March 2020, to calculate the average, maximum, and minimum sea-level height and 
sea-level range for each day and the overall examined time period. The Japanese coastline was divided into 59 sectors, based on similarities in tidal changes during this period (Appendix A).

For marine terraces and beach deposits, IR and RWL with the data and formulas of IMCalc (Lorscheid and Rovere, 2019) were used. Instead of the standard tidal values in IMCalc, the tidal values calculated in this study were utilized. UL and LL for coral terrace proxies or those with relevant molluscan constraints were evaluated manually (Table 3) to reflect a more accurate sea-level range due to proxy formation below sea level. Sea-level extent for coral- or molluscdefined proxies can reach from 0 to $30 \mathrm{~m}$ in Japan but can be further constrained by identifying key species (Yokoyama and Esat, 2015; Nakamori et al., 1995). Coral reef habitat extent ranges from the mean lower low water (MLLW) to the end of the forereef (Rovere et al., 2016). Using the IR and RWL obtained for each sector, UL and LL for coral-terraceand mollusc-constrained proxies were calculated as follows:

$\mathrm{UL}=\mathrm{RWL}-(\mathrm{IR} / 2)$,

$\mathrm{LL}=\mathrm{UL}-\mathrm{MD}_{\mathrm{p}}$,

where RWL, IR, UL, and LL represent the relative water level, indicative range, upper limit, and lower limit, and $\mathrm{MD}_{\mathrm{p}}$ represents the maximum depth of the proxy examined (Table 3).

Paleosea-level and sea-level uncertainties were evaluated within the WALIS database, using the principles outlined in Rovere et al. (2016). Paleosea-levels for each location were calculated using the following formula:

$\mathrm{RSL}_{\mathrm{p}}=E-\mathrm{RWL}$,

where $\mathrm{RLS}_{\mathrm{p}}$ represents the paleosea-level, $E$ is the current proxy elevation, and RWL is the modern relative water level. The associated MoE for each proxy was calculated with the following formula:

$\sigma_{\mathrm{RSL}}=\left[\left(E_{\mathrm{e}}\right)^{2}+(\mathrm{IR} / 2)^{2}\right]^{1 / 2}$,

where $\sigma_{\mathrm{RSL}}$ is the proxy's paleosea-level MoE, $E_{\mathrm{e}}$ is the elevation $\mathrm{MoE}$, and IR is the modern indicative range. Paleosealevel uncertainties are captured within $\sigma_{\mathrm{RSL}}$, with IR of the modern analog describing the range over which the sea-level proxy formed (Shennan, 1982; Van de Plassche, 1986; Hijma et al., 2015; Rovere et al., 2016) and $E_{\mathrm{e}}$ representing uncertainties in the elevation measurements.

Values denoted as averages within our database should be taken as overviews of the data provided for the area and should not be used for rigorous calculations. Paleosea-level calculations and their associated MoE do not directly account for subsidence or uplift that has occurred over its lifetime. Proxy data points were rejected when the background references could not be evaluated or did not provide a usable elevation value.

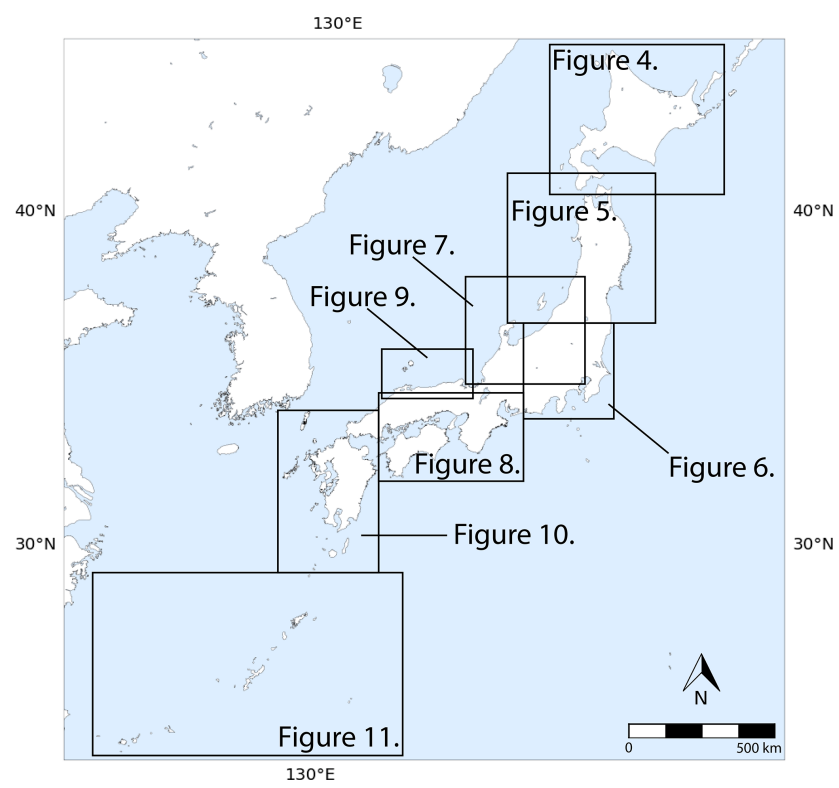

Figure 3. Map of Japan, indicating subsections in which MIS 5e sea-level proxies are examined.

\subsection{Sea-level indicators}

Studies reviewing MIS 5e sea-level proxies in Japan seldom differentiate the term "marine terrace" from other types of sea-level indicators. As such, there is frequently ambiguity in how terraces are defined, especially when utilized as reference points to examine tephra layer relations or to calculate tectonic uplift rates. Terrace composition is often described in studies, but this information is not often utilized to differentiate between types of terraces. Sea-level indicators examined were categorized as marine terraces, beach deposits, and coral reef terraces, as defined in Rovere et al. (2016; Table 1).

\subsection{Elevation details}

Little information was provided in studies reviewed about sea-level proxy elevation data utilized. Some studies reported elevations measured by barometric altimeter, total station or hand level, differential GPS, or using elevations reported on topographic maps, though often the measurement technique was not reported (Table 2). The sea-level datum utilized is relative mean sea level (RLS), namely assumed to be mean sea level (MSL), and does not correct for changes in sea level due to eustacy or glacial isostatic adjustments. Uplift rate margin of errors was not reported in most studies, so procedures outlined in Pedoja et al. (2011) were utilized to calculate rates for studies that reported them. Each proxy elevation MoE was divided by 124000 years and reported in $\mathrm{mm} \mathrm{yr}^{-1}$. Rates were calculated relative to MSL and likewise do not factor in sea-level changes due to eustacy or glacial isostatic adjustments. 
Table 3. Coral assemblage descriptions from reviewed literature used to constrain sea-level margin of error.

\begin{tabular}{|c|c|c|c|c|}
\hline Marine assemblage & $\begin{array}{l}\text { Utilized } \\
\text { reference }\end{array}$ & $\begin{array}{l}\text { Maximum } \\
\text { depth of } \\
\text { proxy } \\
\left(\mathrm{MD}_{\mathrm{p}}\right)\end{array}$ & Depth rationale & Depth reference \\
\hline $\begin{array}{l}\text { Coral assemblage } \\
\text { (no further details) }\end{array}$ & $\begin{array}{l}\text { Koike and } \\
\text { Machida } \\
(2001)\end{array}$ & $30 \mathrm{~m}$ & General coral range & $\begin{array}{l}\text { Yokoyama and Esat } \\
\text { (2015); Nakamori et al. } \\
\text { (1995) }\end{array}$ \\
\hline $\begin{array}{l}\text { Foraminifera: Baculogypsina sphaeru- } \\
\text { lata, Calcarina pengleri, Amphistegina, } \\
\text { Lithophaga curta, Acropora sp., Montipora } \\
\text { sp., Goniastrea sp., Hydnophora exesa, } \\
\text { Symphilla recta }\end{array}$ & $\begin{array}{l}\text { Koba et al. } \\
(1979)\end{array}$ & $\begin{array}{l}5 \mathrm{~m} \text { (reef } \\
\text { crest to } \\
\text { upper } \\
\text { reef } \\
\text { slope) }\end{array}$ & $\begin{array}{l}\text { Baculogypsina sphaerulata: } \\
\text { range within } 5 \mathrm{~m}\end{array}$ & Hosono et al. (2014) \\
\hline Crassostrea gigas & $\begin{array}{l}\text { Miyauchi } \\
(1985)\end{array}$ & $20 \mathrm{~m}$ & Intertidal to subtidal range & Harris (2008) \\
\hline $\begin{array}{l}\text { Mollusca: Arca granosa L., Ostrea palmipe } \\
\text { Sow. cf. multilirata }\end{array}$ & $\begin{array}{l}\text { Yonekura } \\
(1968)\end{array}$ & $\begin{array}{l}\text { Indicative } \\
\text { range }\end{array}$ & $\begin{array}{l}\text { Arca granosa: intertidal zone, } \\
\text { at } 1-2 \mathrm{~m} \text { water depth }\end{array}$ & Pathansali (1966) \\
\hline $\begin{array}{l}\text { Mollusca: Paphia undulata } \\
\text { (Paratapes undulatus) }\end{array}$ & $\begin{array}{l}\text { Ishii et al. } \\
(1994)\end{array}$ & $\begin{array}{l}\text { Indicative } \\
\text { range }\end{array}$ & Inhabits inshore seabed & Paphia undulata (2020) \\
\hline $\begin{array}{l}\text { Mollusca: Patinepecten tokyoensis, Pecten } \\
\text { (Notovola) naganumanus, Psedoamusium } \\
\text { insusicostatum, Pseudoraphitoma naganu- } \\
\text { maensis Ctuka, Mikaithyris hanazawai }\end{array}$ & $\begin{array}{l}\text { Kamada and } \\
\text { Niino } \\
(1955)\end{array}$ & $10 \mathrm{~m}$ & $\begin{array}{l}\text { Typical Patinopecten habitat } \\
\text { range is between } 4-10 \mathrm{~m}\end{array}$ & $\begin{array}{l}\text { Patinopecten yessoen- } \\
\text { sis (FAO, 2020) }\end{array}$ \\
\hline
\end{tabular}

\section{Sea-level proxies: regional overview}

Sea-level proxies as recorded in the WALIS database are described in the following section. These data points were divided into eight regions for description and analysis based on geographic location and regional patterns as follows: Hokkaido; northern Honshu; Kanto; the Noto Peninsula; the Kii Peninsula and Shikoku; Japan seaside consisting of Kansai and Chugoku, Kyushu, and Yamaguchi; and the Ryukyu Islands (Fig. 3). Proxy elevations range between $-85.5 \pm 5$ and $205 \pm 5 \mathrm{~m}$ for all of Japan, and patterns in elevation changes are indicative of tectonic activity across the archipelago. Individual transects within regions can have large variations in proxy elevations (Figs. 4-11), and many of the studies conducted denoting proxy elevations have utilized them to investigate tectonic uplift rates.

\subsection{Hokkaido}

Sea-level proxies in Hokkaido are numerous and have been well documented (Fig. 4). In particular, Okumura (1996) reported terraces across the island, constraining proxies with their relationship to the Toya (112-115 Ka), KP-IV (115$120 \mathrm{Ka}), \mathrm{Kc}-\mathrm{Hb}(115-120 \mathrm{Ka}), \mathrm{ZP}(110-120 \mathrm{Ka})$, and Mb1 (>130 Ka) tephra layers (Fig. 2). The first three ash layers are sourced from Hokkaido volcanoes, specifically from Toya Caldera (Machida et al., 1987) for the former and from the Kutcharo Volcano for the latter two (Hasegawa et al., 2012). 
Table 4. A list of tephra chronohorizons utilized in the reviewed literature. Modified from Machida (2002).

\begin{tabular}{|c|c|c|c|c|c|}
\hline $\begin{array}{l}\text { Chronohorizon } \\
\text { name }\end{array}$ & Abbreviation & Distribution & $\begin{array}{l}\text { Dating } \\
\text { method } \\
\text { utilized }\end{array}$ & Dates (ka) & Reference \\
\hline Toya & Toya & $\begin{array}{l}\text { Northern Japan and } \\
\text { surrounding oceans }\end{array}$ & OI, ST & $112-115$ & Machida et al. (1987) \\
\hline Zarame pumice & $\mathrm{ZP}$ & $\begin{array}{l}\text { Kamikita coastal } \\
\text { plains }\end{array}$ & ST & $110-120$ & Miyauchi (1988) \\
\hline Kutcharo Volcano & $\mathrm{Kc}-\mathrm{Hb}$ & Hokkaido & FT, ST & $115-120$ & Machida et al. (1987); Okumura (1988) \\
\hline Kutcharo pumice flow IV & KP-IV & Hokkaido & ST & $115-120$ & Hasegawa et al. (2012); Machida et al. (1987) \\
\hline Monbetsu tephra & Mb-1 & Hokkaido & ST & $>125$ & Okumura (1991) \\
\hline Daisen-Kurayoshi tephra & DKP & Across Honshu & $\mathrm{ST},{ }^{14} \mathrm{C}, \mathrm{U}$ & 55 & Machida and Arai (1979) \\
\hline Kamitaru pumice & KT & Northern Honshu & ST & $130-150$ & Hayatsu et al. (1982) \\
\hline Furumachi pumice & FR & Northern Honshu & ST & 90 & Hayatsu et al. (1982) \\
\hline Towada-H tephra & To-H & Northern Honshu & ${ }^{14} \mathrm{C}$, OI & 15 & $\begin{array}{l}\text { Machida and Arai (2003); Hayakawa (1990); } \\
\text { Arai et al. (1986) }\end{array}$ \\
\hline Naruko-Yanagisawa & $\mathrm{Nr}-\mathrm{Y}$ & Northern Honshu & ${ }^{14} \mathrm{C}, \mathrm{OSL}, \mathrm{FT}$ & $41-63$ & Machida and Arai (2003) \\
\hline Naruko-Nisaka tephra & $\mathrm{Nr}-\mathrm{N}$ & Northern Honshu & ST & 90 & Machida and Arai (2003) \\
\hline Dokusawa tephra & DKS & Northern Honshu & ST & $90-100$ & Matsuura et al. (2009) \\
\hline Tanabu tephra & $\operatorname{Tn}(\mathrm{A}-\mathrm{C})$ & Northern Honshu & ST, OI & MIS 7-MIS 8 & Matsuura et al. (2014) \\
\hline Ontake-1 pumice & On-Pm1 & $\begin{array}{l}\text { Central to northern } \\
\text { Honshu }\end{array}$ & FT, K-Ar, ST & ca. 100 & Machida and Arai (2003) \\
\hline Sambe-Kisuki tephra & SK & Across Honshu & ST & $110-115$ & Toyokura et al. (1991) \\
\hline Shimosueyoshi loam & & $\begin{array}{l}\text { In and around } \\
\text { Yokohama }\end{array}$ & FT & $120-130$ & Toma (1974) \\
\hline $\begin{array}{l}\text { Hakone pumice fall } \\
\text { deposit }\end{array}$ & Hk-KIP-7 & $\begin{array}{l}\text { Chubu-Kanto } \\
\text { (central Japan) }\end{array}$ & ST & 130 & Suzuki (1992) \\
\hline $\begin{array}{l}\text { Hakone Kissawa pumice } \\
\text { layer }\end{array}$ & Hk-KIP-8 & $\begin{array}{l}\text { Chubu-Kanto } \\
\text { (central Japan) }\end{array}$ & FT & 132 & Suzuki (1992) \\
\hline $\begin{array}{l}\text { Miwa Lower pumice } \\
\text { layer }\end{array}$ & Miwa-L & $\begin{array}{l}\text { Chubu-Kanto } \\
\text { (central Japan) }\end{array}$ & ST & 130 & Suzuki (1992) \\
\hline Hakone-Tokyo pumice & Hk-Tp & Around Tokyo & OSL & $67.5 \pm 4.3$ & Machida et al. (1987); Tsukamoto et al. (2010) \\
\hline Matsue tephra & DMP & Chugoku and Shikoku & ST & $110-120$ & Inoue et al. (2005); Miura and Hayashi (1991) \\
\hline Aso-3 tephra & Aso-3 & $\begin{array}{l}\text { Central Kyushu - } \\
\text { central Honshu }\end{array}$ & $\mathrm{FT}, \mathrm{K}-\mathrm{Ar}, \mathrm{ST}$ & $120-135$ & Machida and Arai (2003) \\
\hline Ata tephra & Ata & In and around Japan & $\mathrm{K}-\mathrm{Ar}, \mathrm{ST}$ & $105-110$ & Machida and Arai (2003) \\
\hline Aira-Tanzawa tephra & $\mathrm{AT}$ & In and around Japan & ${ }^{14} \mathrm{C}$ & $25.12 \pm 0.27$ & Machida (2002); Miyairi et al. (2004) \\
\hline Aso-4 tephra & Aso-4 & In and around Japan & OI, K-Ar, ST & $87-89$ & Takarada and Hoshizumi (2020) \\
\hline Kikai-Tanazawa tephra & $\mathrm{K}-\mathrm{Tz}$ & In and around Japan & ST, TL & $75-80$ & Machida and Arai (2003) \\
\hline
\end{tabular}

* OI: oxygen isotope dating; ST: stratigraphy correlation; FT: fission-track dating; ${ }^{14} \mathrm{C}$ : carbon-14 dating; K-Ar: potassium-argon dating; OSL: optically stimulated luminescence dating; U: uranium-thorium dating.

Sea-level proxies in Hokkaido can be examined in five subregions: northeast, southeast, northwest, southwest, and the western cape. Proxies on the northeastern edge of Hokkaido are age constrained by the Toya, KP-IV, Kc-Hb, and $\mathrm{Mb}-1$ tephra layers and are low in elevation compared to the rest of the island. Elevations generally range between $6 \pm 1.20-18 \pm 7.60 \mathrm{~m}$. The proxies closer to the $\mathrm{Ne}-$ muro Strait increase from $33.50 \pm 35.70-80 \pm 16 \mathrm{~m}$. Proxies along the southeastern edge of Hokkaido are constrained predominantly by the Toya and KP-IV tephras but addition- ally by the ZP and Kc-Hb layers (Okumura, 1996; Koike and Machida, 2001; Machida et al., 1987). Higher elevations can be found towards the center $(35 \pm 7-60 \pm 12 \mathrm{~m})$, decreasing moving outwards $(15 \pm 3-32.50 \pm 11.5 \mathrm{~m})$. Both the northeastern and southeastern edges are described along several transects by Okumura (1996), and marine terraces correlated to the last interglacial period have been designated as M1 stage terraces, which are often observed in sequence with $\mathrm{H} 1$, $\mathrm{H} 2$, and M2 terraces. M1 terraces are composed of marine 


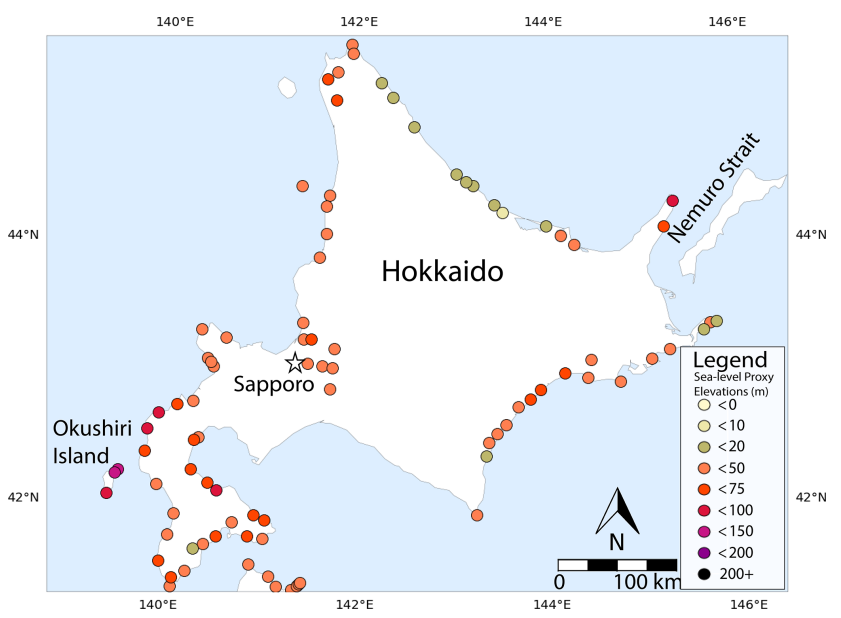

Figure 4. Sea-level elevation proxies in Hokkaido. Sea-level indicators (circles) with elevation range indicated by color (see legend). Reference cities are indicated by stars.

sediments and overlie fluvial gravel, though no other terrace descriptions are provided.

Elevations of sea-level proxies on the northwestern edge of Hokkaido generally range between $40 \pm 8-45 \pm 9 \mathrm{~m}$ in elevation, though on the northern tip proxies range from $40 \pm 8-61 \pm 32.20 \mathrm{~m}$. Inland marine terraces near Sapporo range from $30 \pm 6-52.50 \pm 15.50 \mathrm{~m}$ in elevation. Sea-level proxy ages are defined primarily through stratigraphic correlation, though a few are directly constrained by Toya and $\mathrm{Kc}-\mathrm{Hb}$ tephra layers (Koike and Machida, 2001; Machida et al., 1987). Sea-level proxies on the western arm of Hokkaido vary between $20 \pm 1-130 \pm 10 \mathrm{~m}$ in elevation, with lower elevations in areas further to the north or south $(20 \pm 1-$ $45 \pm 25 \mathrm{~m}$ ). Proxies toward the center of this range have elevations between $55 \pm 21-130 \pm 26 \mathrm{~m}$, with the highest elevations found on Okushiri Island. Terraces on the eastern side of the arm also have higher elevations (50 $\pm 30-90 \pm 38 \mathrm{~m})$. Ages are constrained primarily by use of the Toya tephra and stratigraphic relationships (Koike and Machida, 2001; Machida et al., 1987), though ZP layers are also found at select locations including Okushiri Island (Miyauchi, 1988). While sea-level proxies for southwestern Hokkaido have been studied (Yoshiyama, 1990), elevation values were not specifically recorded.

\subsection{Northern Honshu}

Recorded elevations of sea-level proxies in northern Honshu can be subdivided into Mutsu Bay-Shimokita Peninsula, upper eastern, lower eastern, and western regions (Fig. 5). Marine terraces are well defined and categorized on the eastern edge, and they are recognized and named as the Fukuromachi, Shichihyaku, Tengutai, Takadate, Nejo, and Shibayama terraces around the Kamikita Plains (upper section of the eastern region; Miyauchi, 1985, 1987; Koike and

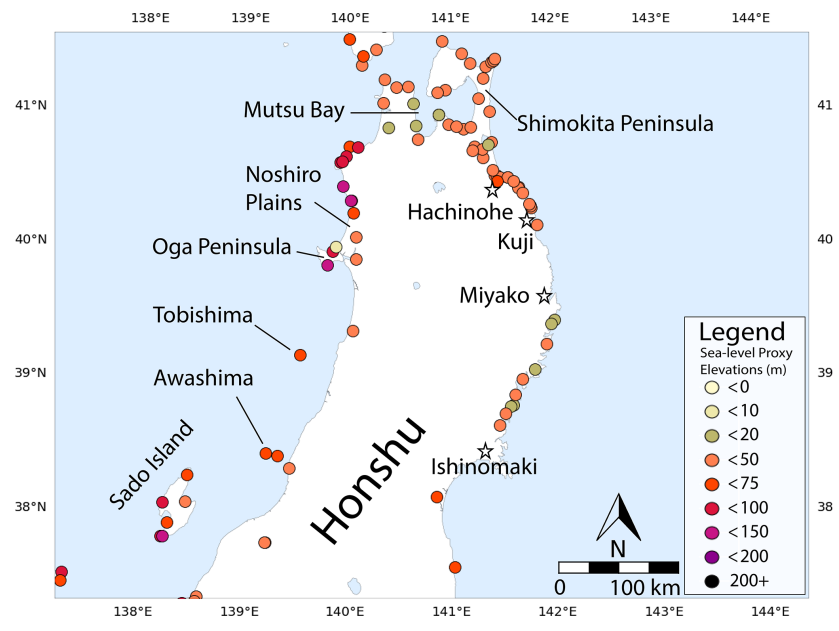

Figure 5. Sea-level elevation proxies in northern Honshu. Sea-level indicators (circles) with elevation range indicated by color (see legend). Reference cities are indicated by stars.

Machida, 2001), with the sand-gravel marine deposit Takadate terrace constrained by the Toya tephra to correlate to MIS 5e (Miyauchi, 1985; Ito et al., 2017). Proxies in northern Honshu are constrained by the Toya tephra and the ZP layer (Miyauchi, 1988; Machida et al., 1987) and stratigraphic correlation. The relatively detailed understanding of terrace layers and age constraints in this region has encouraged trials of pIRIR OSL dating in this region (Ito et al., 2017; Thiel et al., 2015), establishing it as a viable dating method for marine sediments.

Sea-level proxy elevations around Mutsu Bay itself range between $13.5 \pm 3.70-35 \pm 22 \mathrm{~m}$, while further north on the Shimokita Peninsula proxy elevations range between $30 \pm 6$ $50 \pm 10 \mathrm{~m}$. Terraces are generally constrained by the Toya tephra and the ZP layer, but Tanabu A, B, C (MIS 7-8; Matsuura et al., 2014) tephra layers have also been identified to underlie MIS 5e terraces at certain sites. More recent studies from Matsuura et al. (2014) and Watanabe et al. (2008) have explored marine terraces on the Shimokita Peninsula in depth to examine regional tectonic uplift and deformation.

Terraces on upper eastern side of northern Honshu have elevations between $15 \pm 0.08-51 \pm 2 \mathrm{~m}$ overall, though generally they range between $35-45 \mathrm{~m}$ from the bottom of the Shimokita Peninsula down towards Hachinohe. Between Hachinohe and Kuji, sea-level proxy elevations vary between $22.25 \pm 5-48.50 \pm 3 \mathrm{~m}$, though most are between $25-30 \mathrm{~m}$, generally decreasing towards the south. Most terraces are constrained by an observed Toya tephra layer, and in some areas by the ZP layer. OSL ages from AIST $(2015,2016)$ and Ito et al. (2017) for MIS 5e terraces as examined in Matsuura et al. (2019) are noted to align with results from tephrochronology, though OSL ages from terraces representing MIS 7 and 9 from the same studies were found not to match tephrochronologically restrained ages. Sea-level prox- 


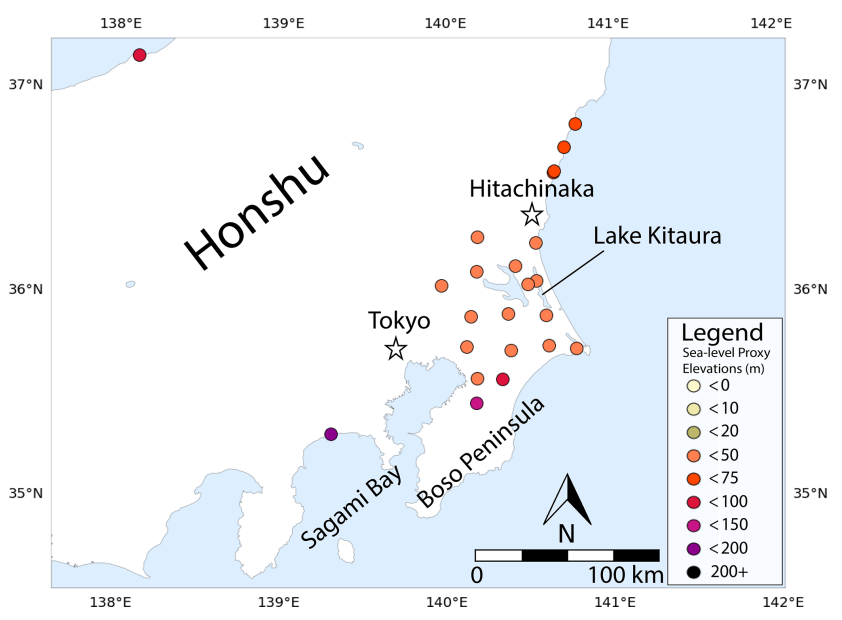

Figure 6. Sea-level elevation proxies in the Kanto region. Sea-level indicators (circles) elevation range indicated by color (see legend). Reference cities are indicated by stars.

ies in this transect are identified by their beach deposit sequences, mainly silt, sand, and gravel deposits (Miyazaki and Ishimura, 2018; Miyauchi, 1985).

On the lower eastern side between Miyako and Ishinomaki, sea-level proxy elevations varied between $17.83 \pm 8.56-25.33 \pm 11.10 \mathrm{~m}$. Ages were constrained through stratigraphic correlation (Koike and Machida, 2001; Miura, 1966), and the DKS tephra layer was observed in Matsuura et al. (2009). Terraces reported in Miura (1966) were initially correlated to the Shimosueyoshi interglacial period, which has since been reinterpreted as the last interglacial period. Terraces reported by Matsuura et al. (2009) were described wave cut benches. Proxies south of Ishinomaki had relatively higher elevations $(60 \pm 12$, $67.50 \pm 18.50 \mathrm{~m})$.

Sea-level proxies on the western side of northern Honshu are lower in elevation towards the northern tip $(19.25 \pm 14.85-30 \pm 6 \mathrm{~m})$, and drastically increase moving south $(72 \pm 54.50-140 \pm 28 \mathrm{~m})$. Proxy elevations decrease to $45.5 \pm 14.5-53.67 \pm 26 \mathrm{~m}$ in the Noshiro Plain (Miyauchi, 1988; Naito, 1977). Two locations have significantly lower elevations of $2.5 \pm 0.5 \mathrm{~m}$ (Thiel et al., 2015) and $21 \pm 18 \mathrm{~m}$ (Naito, 1977), though ages for the former were well constrained by both tephrochronology and pIRIR OSL dates. Elevations of terraces found on the Oga Peninsula are relatively high $(80 \pm 16 \mathrm{~m}, 130 \pm 26 \mathrm{~m}$, Miyauchi, 1988), and proxies found south of this range from $25-45 \mathrm{~m}$. Sea-level proxy heights are also found on islands along the western shoreline, including Tobishima $(58.88 \pm 23.80 \mathrm{~m})$, Awashima $(54.55 \pm 21.93 \mathrm{~m})$, and Sado Island $(45.57 \pm 20.02-120 \pm 24 \mathrm{~m})$. Age correlations were made through mainly the Toya and ZP tephra layers, though $\mathrm{K}-\mathrm{Tz}$ and SK tephra layers were also noted (Watanabe and Une, 1985; Koike and Machida, 2001).

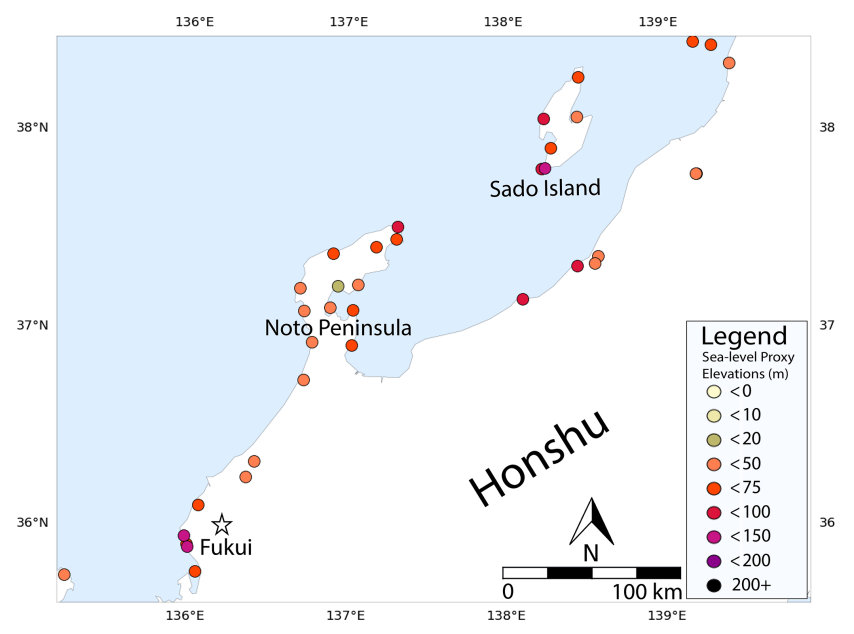

Figure 7. Sea-level elevation around the Noto Peninsula. Sea-level indicators (circles) with elevation range indicated by color (see legend). Reference cities are indicated by stars.

\subsection{Kanto}

Studies identifying sea-level proxies from the last interglacial in Kanto denote terraces mainly in Ibaraki and Chiba prefectures (Fig. 6). Tephra utilized to constrain sea-level proxy ages are sourced predominantly from Mt. Hakone (Hk-Tp, Hk-KIP-8, Hk-KIP-7), though Miwa-L, K-Tz layers, and Shimosueyoshi loam are also utilized in this region.

Sea-level proxies in the upper part of Ibaraki prefecture (north of Hitachinaka) have elevations between $52.75 \pm 11.55-74 \pm 14.80 \mathrm{~m}$, decreasing towards the south, and are chronostratigraphically constrained mainly by the Miwa-L pumice layer, in addition to the $\mathrm{K}-\mathrm{Tz}$ and HkKIP-7 layers (Suzuki, 1989). In the Joban region to the south, sea-level proxies are observed with elevations between $23.23 \pm 9.46-50 \pm 10 \mathrm{~m}$, and increasing drastically south on the Boso Peninsula (maximum elevation of $130 \pm 10 \mathrm{~m}$; Sugihara, 1970; Koike and Machida, 2001; Kaizuka, 1987). The tilting towards the northeast is thought to be at least partially due to uplift related to Sagami trench subduction to the southwest of the Boso Peninsula (Tamura et al., 2010). Proxies are mainly constrained by the presence of Miwa-L and Hk-KIP-8 layers, in addition to Hk-Tp, On-Pm1, and the Shimsueyoshi loam (Suzuki, 1989; Suzuki, 1992). ${ }^{14} \mathrm{C}$ dating was utilized on identified molluscs (Crassotrea gigas) to constrain a MIS 1 stage terrace and correlate other highstand-related terraces accordingly at Yokaichiba (Koike and Machida, 2001). OSL dating using quartz grains identified ages of shallow marine sediments from near Lake Kitaura, identifying sequences correlated to MIS 5e-5c (Hataya and Shirai, 2003). One sealevel proxy was denoted in Sagami Bay $(160 \pm 32 \mathrm{~m})$, and other locations in the bay have been studied, though elevation values were not reported (Koike and Machida, 2001; Machida, 1973). 


\subsection{The Noto Peninsula}

Sea-level proxies on the Noto Peninsula itself are primarily age constrained through general stratigraphic correlation, though tephra layers are more numerously identified in locations to the east and the southwest (Fig. 7). East of the peninsula, the easternmost two terrace elevations continue lower elevations seen in northern Honshu $(30 \pm 6$, $45 \pm 49 \mathrm{~m}$ ), but moving west towards the peninsula elevations are higher $(81.67 \pm 21.33,85 \pm 17 \mathrm{~m})$ and are age constrained by FR pumice and KT layers (Koike and Machida, 2001). On the Noto Peninsula, the northern tip has generally higher elevations (maximum at $85.44 \pm 69.08 \mathrm{~m}$ ) that decrease significantly towards the middle of the peninsula $(18.06 \pm 14.61-36.09 \pm 38.20 \mathrm{~m})$ and increase proceeding south $(37.62 \pm 44.52-52.55 \pm 16.51 \mathrm{~m})$, aligning with the southward tilting of the peninsula observed by Ota and Hirakawa (1979). Age constraints of sea-level proxies on the Noto Peninsula are mainly from stratigraphic correlations, though the Shimosueyoshi loam layer has also been identified (Toma, 1974).

South of the peninsula sea-level proxy elevations range between $31.75 \pm 36.35-46 \pm 42.2 \mathrm{~m}$ and increase near Fukui $(67.13 \pm 115.42-117.71 \pm 42.50 \mathrm{~m})$. Terrace ages are mainly constrained by DKP and AT tephra layers, especially terraces found south of Fukui, though SK and Aso-4 tephra layers have also been identified (Yamamoto et al., 1996; Koike and Machida, 2001).

\subsection{The Kii Peninsula and Shikoku}

Sea-level proxies found on the Kii Peninsula and the Shikoku region can be subcategorized into five sections: eastern Kii, western Kii, Osaka Bay, eastern Shikoku, and western Shikoku (Fig. 8). Age constraints for proxies in this general region are determined primarily through stratigraphic correlation, though K-Tz, AT tephra layers, and amino acid racemization dates were utilized in select studies.

Sea-level proxy locations on the eastern side of the Kii Peninsula range between $20 \pm 14-40 \pm 8 \mathrm{~m}$ and utilize stratigraphic correlation to constrain ages to MIS 5e (Muto, 1989; Hiroki, 1994; Koike and Machida, 2001), though several additional locations have been reported without elevations around Mikawa Bay (Koike and Machida, 2001). Elevations on the western side of the Kii Peninsula generally increase towards the southern tip from $18.75 \pm 5.33-63.17 \pm 7.28 \mathrm{~m}$ and rely on stratigraphic correlation to MIS 5e (Yonekura, 1968; Koike and Machida, 2001). Seven terrace levels are reported $\left(\mathrm{H}_{1}-\mathrm{H}_{4}\right.$ and $\mathrm{L}_{1}-\mathrm{L}_{3}$, with $\mathrm{L}_{1}$ representing MIS 5e) and are described as wave-based erosionally formed marine terraces, covered by later deposited sand and gravel layers (Yonekura, 1968). Proxies around Osaka Bay exhibited elevations of $34.80 \pm 26.96-59 \pm 44.80 \mathrm{~m}$ with lower elevations on the eastern side of the bay and higher elevations to the north-northwestern side. Proxies on Awaji-shima

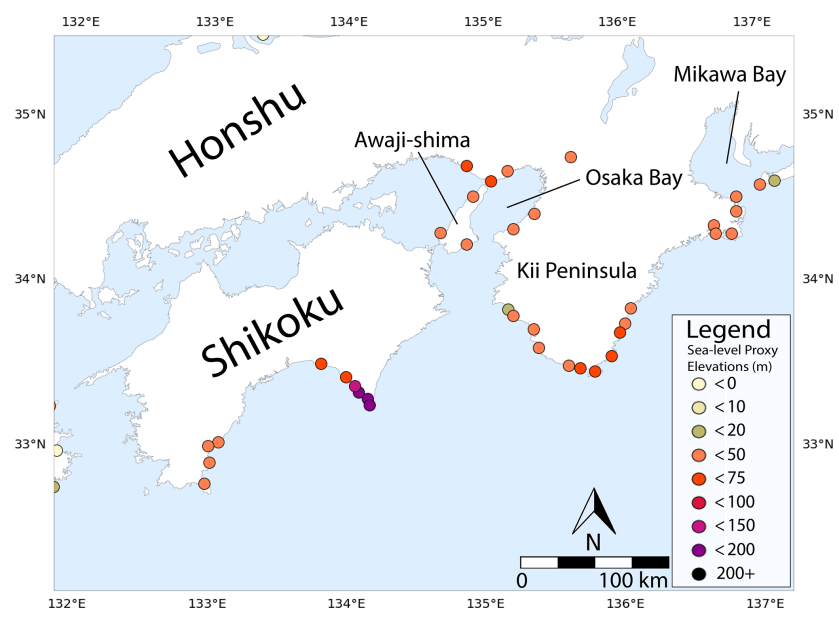

Figure 8. Sea-level elevation proxies in Shikoku and the Kii Peninsula. Sea-level indicators (circles) with elevation range indicated by color (see legend)

are between $41.25 \pm 13.25-45 \pm 9 \mathrm{~m}$, with one location constrained by AT tephra (Koike and Machida, 2001; Machida, 2002).

Elevations of proxies studied on the eastern side of Shikoku range widely between $57.80 \pm 27.60$ $173 \pm 34.60 \mathrm{~m}$, increasing towards the southern tip (Yoshikawa et al., 1964; Yonekura, 1968; Matsuura, 2015; Mizutani, 1996; Koike and Machida, 2001). The terraces are identified by their inner edges, with boulders through fine silt as terrace deposits (Matsuura, 2015). Older studies utilize stratigraphic correlation to constrain ages, though several tephra layers including the $\mathrm{K}-\mathrm{Tz}$ layer are recognized by Matsuura (2015). Western Shikoku has a small number of evaluated proxies, with elevations ranging from $26 \pm 5.20-36.58 \pm 28.30 \mathrm{~m}$ (Ota and Odagiri, 1994; Koike and Machida, 2001). Five terrace layers were identified $\left(\mathrm{H}_{1}-\mathrm{H}_{3}, \mathrm{M}, \mathrm{L}\right)$, with the $\mathrm{M}$ terrace recognized as representing MIS 5e (Ota and Odagiri, 1994). Ages from shell amino acid racemization of an underlying layer (ca. $138 \mathrm{ka}$ ) and overlying $\mathrm{K}-\mathrm{Tz}$ tephra were used to constrain terrace layer ages (Ota and Odagiri, 1994; Mitsushio et al., 1989).

\subsection{Japan sea side: Kansai and Chugoku}

Few studies have been performed in this region identifying MIS 5e sea-level proxies (Fig. 9). Two marine terraces by Wakasa Bay (elevations of $40 \pm 8,50 \pm 10 \mathrm{~m}$ ) were age constrained from stratigraphic correlation. One submerged sealevel indicator was observed through seismic surveys of sediments in Miho Bay and identified MIS 5e-associated sediment layers at a depth of $-42 \pm .08 \mathrm{~m}$ constrained by DMP tephra (Inoue et al., 2005). Additional locations in Kyoto, Tottori, and Shimane prefectures (Machida and Arai, 1979; 


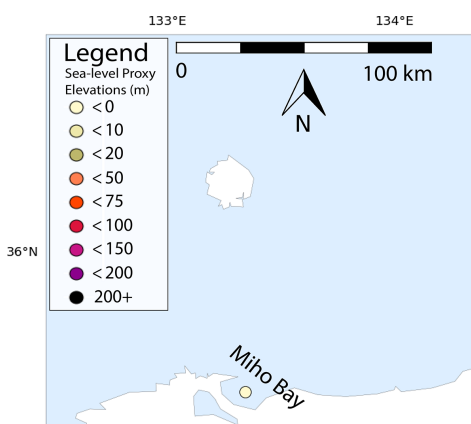

Shimane Prefecture $135^{\circ} \mathrm{E}$

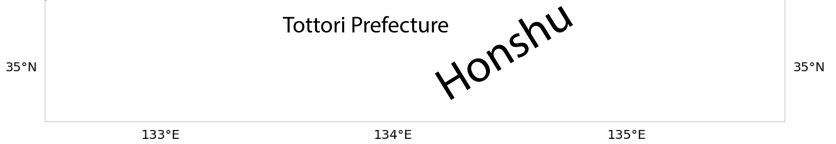

Figure 9. Sea-level elevation proxies along the Japan Sea (Kansai and Chugoku). Sea-level indicators (circles) with elevation range indicated by color (see legend).

Koike and Machida, 2001) have been studied but were reported without elevation values.

\subsection{Kyushu and Yamaguchi}

Numerous sea-level proxies have been identified in Kyushu and Yamaguchi, with most elevations identified with low to negative values (Fig. 10). Kyushu is a source of several key indicator tephra layers, and many sea-level proxies are well constrained by the Ata and Aso-4 layers. This region can be examined in five subsections: Yamaguchi, northern Kyushu, eastern Kyushu, southern Kyushu, and western Kyushu. A substantial number of sea-level proxies from around Kyushu were collected by Shimoyama et al. (1999), using molluscan fossil assemblages from both the intertidal and subtidal ranges to determine the marine top height.

Proxies found along the inland sea in Yamaguchi have elevations between $16.10 \pm 9.20-20.70 \pm 17.10 \mathrm{~m}$ and are age constrained by both the Aso-4 tephra layer and stratigraphic correlation (Koike and Machida, 2001). In the northern section of Kyushu, terrace elevations between $-7.5 \pm 0.40$ and $-8.1 \pm 0.4 \mathrm{~m}$ are reported, constrained by Ata tephra, in addition to the terrace at $11.80 \pm 2.40 \mathrm{~m}$ constrained by stratigraphy. On the eastern edge of Kyushu, sea-level proxies near Oita generally range between $20.70 \pm 0.40$ $50 \pm 10 \mathrm{~m}$ in elevation, in addition to one submerged proxy $(-85.50 \pm 0.40 \mathrm{~m})$. Until Nobeoka, terrace elevations are between $-29.90 \pm 0.40$ and $18.75 \pm 6.25 \mathrm{~m}$. Sealevel proxies south of this appear as both a high-elevation set $(74 \pm 14.8-107 \pm 0.4 \mathrm{~m})$ and lower elevations $(32 \pm 6.4$, $33.33 \pm 16.66 \mathrm{~m})$. Ages for eastern Kyushu are typically correlated between Aso-3 and Ata tephra layers, in addition to the Aso-4 layer and general stratigraphic correlation (Shimoyama, et al., 1999; Chida, 1974; Koike and Machida, 2001; Nagaoka et al., 2010).

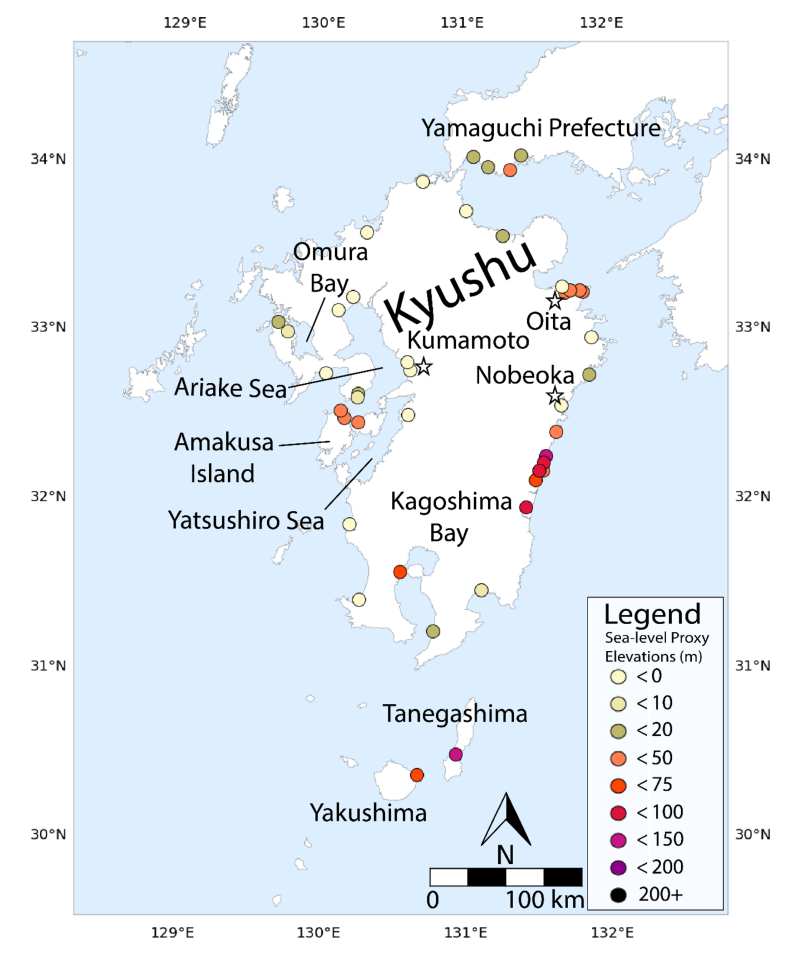

Figure 10. Sea-level elevation proxies in Kyushu and Yamaguchi. Sea-level indicators (circles) with elevation range indicated by color (see legend). Reference cities are indicated by stars.

At least five sea-level proxies have been identified on the southern coast of Kyushu. Terraces associated with Kagoshima Bay have higher elevations $(15.6 \pm 0.4 \mathrm{~m}$, $52.3 \pm 0.4 \mathrm{~m})$ than those on the coast $(6.1 \pm 0.4$ to $-39 \pm 0.4 \mathrm{~m}$ ). Elevations of proxies on the islands directly south of Kyushu are recorded at $51.5 \pm 0.4 \mathrm{~m}$ (Yakushima) and $120 \pm 0.4 \mathrm{~m}$ (Tanegashima) and are substantially higher at Tanegashima. Terraces in southern Kyushu are all well constrained between Ata and Aso-3 tephra layers (Shimoyama et al., 1999). On the western side of Kyushu, sealevel indicators in proximity to the Ariake and Yatsushiro seas have lower elevations $(-63.1 \pm 0.4$ to $12.7 \pm 0.4 \mathrm{~m})$. Proxies on Amakusa Island are comparatively higher $(27.71 \pm 15.54-45 \pm 9 \mathrm{~m})$ and again lower near Omura Bay $(7 \pm 1.4,13.33 \pm 12.66 \mathrm{~m})$. Ages are mainly constrained between Ata and Aso-3 tephras, though some locations utilize Aso-4 or stratigraphic correlation (Shimoyama et al., 1999; Kamada and Niino, 1955; Koike and Machida, 2001).

\subsection{The Ryukyu Islands}

Sea-level proxies in the Ryukyu Islands are here categorized in three groups: north of Okinawa, Okinawa and the Daito Islands, and west of Okinawa (Fig. 11). Most sea-level indicators found in the Ryukyu Islands are coral terraces, allowing for direct U-Th dating of terraces and ${ }^{14} \mathrm{C}$ dating of lower terraces to constrain higher MIS highstand-correlated ter- 


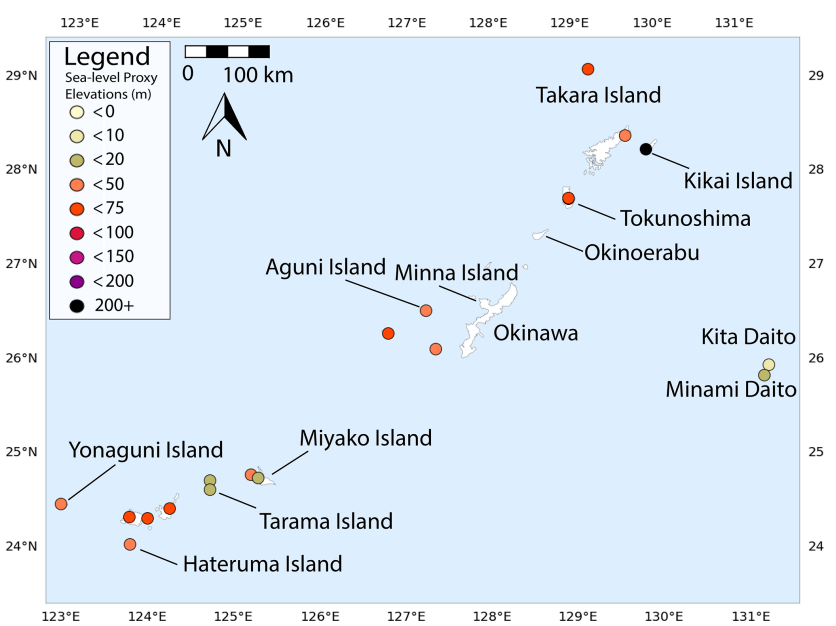

Figure 11. Sea-level elevation proxies in the Ryukyu Islands. Sealevel indicators (circles) with elevation range indicated by color (see legend).

race platform series. Elevations of MIS 5e-correlated terraces north of Okinawa range from $43.95 \pm 46.79-66.58 \pm 103 \mathrm{~m}$, aside from Kikai Island at $245 \pm 5 \mathrm{~m}$. Direct dates of corresponding terraces from U-Th were taken at Kikai Island $(122.1 \pm 3.8 \mathrm{ka})$ and Tokunoshima $(125 \pm 10 \mathrm{ka}) .{ }^{14} \mathrm{C}$ dates on Takara Island ( $2.3 \pm 0.15-3.3 \pm 0.13 \mathrm{ka})$ were used to correlate MIS 5e terrace dates (Koba et al., 1979; Ikeda, 1977; Inagaki and Omura, 2006; Koike and Machida, 2001).

On the Okinawa-adjacent islands, elevations for sea-level proxies ranged between $23.33 \pm 14.66-55.75 \pm 21.15 \mathrm{~m}$. Ages were constrained through stratigraphic correlation, and at Aguni Island younger terraces were dated at $33.7 \mathrm{ka} \mathrm{by}{ }^{14} \mathrm{C}$ dating. On Minami and Kita Daito, elevations were measured at $12.45 \pm 2.49$ and $10 \pm 2 \mathrm{~m}$, and $\mathrm{U}-\mathrm{Th}$ dates were averaged at $123 \pm 5$ and $123 \pm 6$ ka respectively (Omura et al., 1991; Koike and Machida, 2001; Ota and Omura, 1992). West of Okinawa, proxy elevations fell into two groups: between $11 \pm 2.2-25 \pm 15 \mathrm{~m}$ (Miyako, Yonaguni, Minna, and Tarama islands) and $41 \pm 8.2-60.17 \pm 46 \mathrm{~m}$ (islands near Ishigaki Island). U-Th ages were calculated from coral limestones at Hateruma Island $(128 \pm 7 \mathrm{ka})$, and ages were otherwise constrained through stratigraphic correlation (Omura et al., 1994; Ota and Omura, 1992; Koike and Machida, 2001).

\section{Further details on sea-level proxies around Japan}

\subsection{Data quality}

The data quality from studies examining MIS 5e sea-level proxies in and around Japan is considered scientifically reliable. Age constraints provided for studies are generally well supported, reporting the dating technique or rationale for age assignments for specific sea-level proxies. As mentioned in Sect. 2, use of chronohorizons can introduce larger age constraint MoEs and can be considered suboptimal since terrace ages and MIS stages are correlated from chronostratigraphical relationships. However, due to the abundant distribution and detailed analysis of tephra in Japan, these techniques and results are considered reliable.

Details about elevation measurement styles were reported infrequently and inconsistently across the studies analyzed. Though some older studies often reported use of devices such as a Paulin altimeter MT-2 (e.g., Yonekura, 1968), others either did not report or did not clearly articulate measurement styles. As a result, many studies have larger MoEs assigned to sea-level proxy elevations. Sea-level proxy type assignments are similarly infrequently delineated, with some studies listing sea-level proxies as marine terraces despite composition details (such as coral reef terraces). Others provided little to no characteristics of the marine terraces themselves. As explored in Sect. 3, these details can change the interpretation of sea-level extent. Future studies could benefit from more rigorous descriptions of elevation measurement styles, sea-level proxy compositions, and details on sea-level proxy type assignments.

Data entered into the WALIS database were reported with relative sea level (RSL) and age quality ratings on a $0-5$ scale rating, with 5 representing the highest value. Age quality ratings were assigned on age reliability, categorizing studies with direct dating on sea-level proxies as most reliable (5), followed by studies interpreting sea-level proxies using directly dated or constrained chronohorizons such as tephra (4), studies utilizing regional stratigraphic relationships without numerical age dating to interpret sealevel proxy ages (3), and studies using poorly described chronohorizons (2). Sea-level proxies reported in compilation databases but deemed unverifiable due to missing source references were assigned the lowest ratings $(0-1)$ but were omitted from this database.

RSL quality ratings were assigned using the same $1-5$ scale rating. Studies were assessed on their description of sea-level proxies, including details about composition (including sediment types and identified coral/mollusc species) and sea-level proxy type assignment (such as identification of the inner margin of a marine terraces). Studies were assigned between $2-5$, scaling between vague (2) and highly detailed descriptions (5). Uncertainties about sea-level proxy elevations such as rounding of elevation values of sea-level proxies were assigned low ratings (2). Sea-level proxies with elevation MoEs over $60 \%$ of the original elevation were also assigned low ratings (1). For proxies with large MoEs due to averaging, results are likely less representative of the measurement accuracy but rather indicative of the large range of sea-level proxy elevations due to regional tectonic uplift. Specific regions can have large changes in overall area, as can been seen on the Boso Peninsula (Fig. 6), Sado Island (Fig. 7), and eastern Shikoku (Fig. 8). Entries with the lowest rating (0) were not included in the database, representing data from studies that could not be located. 


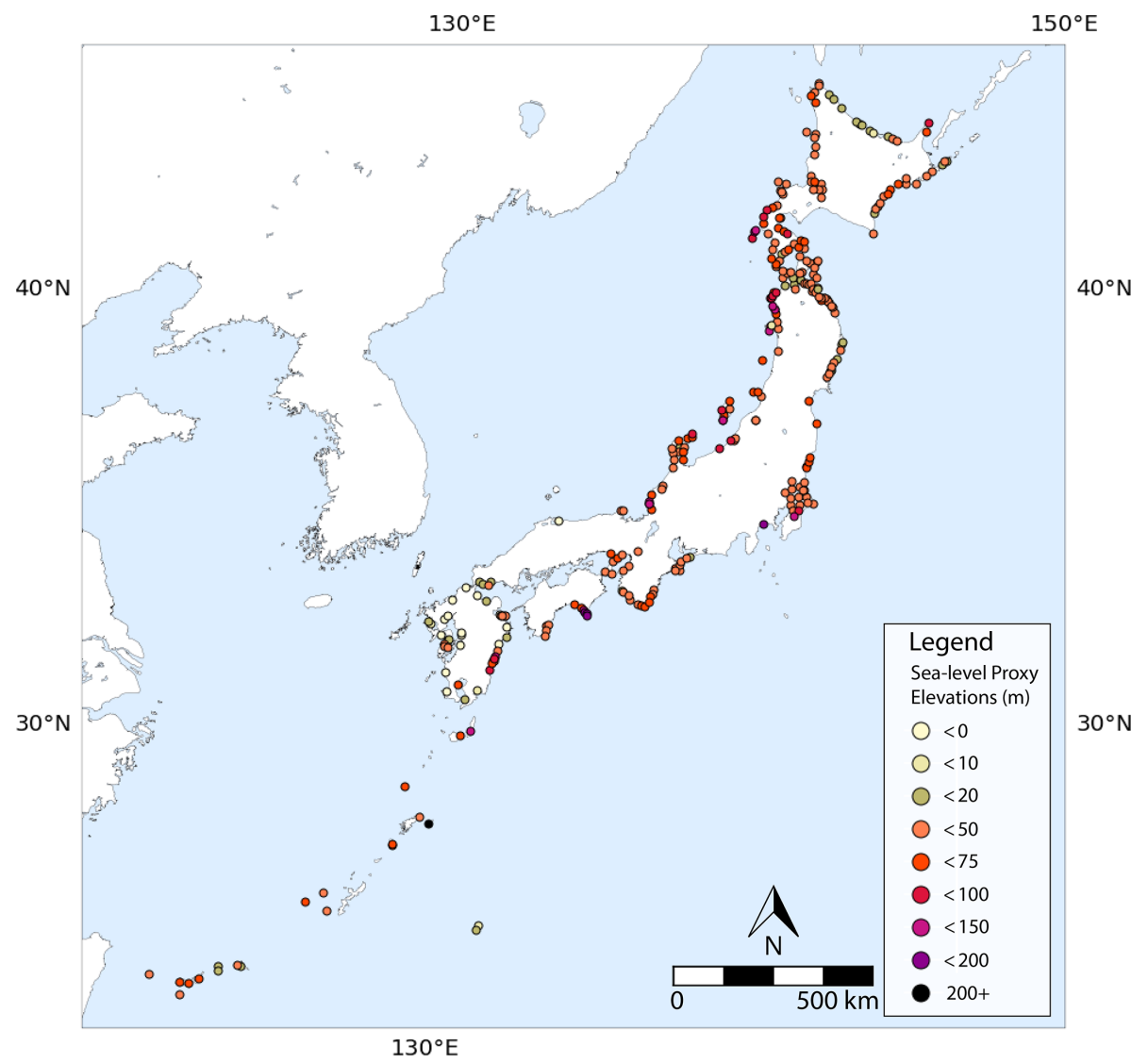

Figure 12. Sea-level elevation proxies over the Japanese archipelago. Sea-level indicators (circles) and elevation range indicated by color (see legend).

\subsection{MIS 5e sea-level fluctuations}

Overall, precise regional sea-level fluctuation analysis for the entire Japanese archipelago during MIS 5e has not been conducted and would be difficult to constrain due to the nature of age assignments historically utilized in most studies. As use of chronohorizons and tephrochronology constrain stratigraphic layers to or between separately analyzed proxies, precise timing of sea-level changes has not been emphasized in studies and can be difficult to quantify. Chronohorizons that have been themselves correlatively age constrained are common, increasing the possible margin of dating error. Studies have utilized numerical age dating techniques around Japan on sea-level proxies themselves, but use beyond the Ryukyu Islands has thus far been limited (e.g., Koba et al., 1979; Inagaki and Omura, 2006). Increased use of numerical age dating across Japan would allow for deeper crossregional analyses of MIS 5e sea-level fluctuations.

\subsection{Other sea-level highstands}

Numerous studies have interpreted sea-level proxies in Japan to correlate with other sea-level highstands. Sea-level indicators representing MIS 11 (e.g., Hiroki, 1994), 9 (e.g., Mat- suura et al., 2014; Amano et al., 2018), 7 (e.g., Ota and Omura, 1992; Miyazaki and Ishimura, 2018), 5 a-c (e.g., Inagaki and Omura, 2006; Miyauchi, 1988), and 3 (e.g., Sasaki et al., 2004; Omura et al., 2000) are abundant in the literature. Staircase terrace sea-level proxies are commonly identified, so individual studies frequently describe several highstands or interglacial sea levels. Age constraints for these periods utilize and thus suffer from the same limitations of techniques mentioned in Sect. 2.

\subsection{Holocene sea-level indicators}

Studies on Holocene sea-level indicators are more abundant than those focusing on MIS 5e in Japan. Several reviews of Holocene sea-level changes around Japan have been compiled, such as in "Atlas of Holocene Sea Level Records in Japan" (Ota et al., 1981) and "Atlas of Late Quaternary Sea Level Records in Japan, volume 1" (Ota et al., 1987). As such, sea-level change since the Last Glacial Maximum in Japan is well characterized both overall and by region (Umitsu, 1991). Unlike MIS 5e sea-level proxies, ${ }^{14} \mathrm{C}$ dating has been utilized as a numerical age dating method on sea-level proxies rather than designating ages to a chronohorizon and sees much use on coral reefs that emerged during 


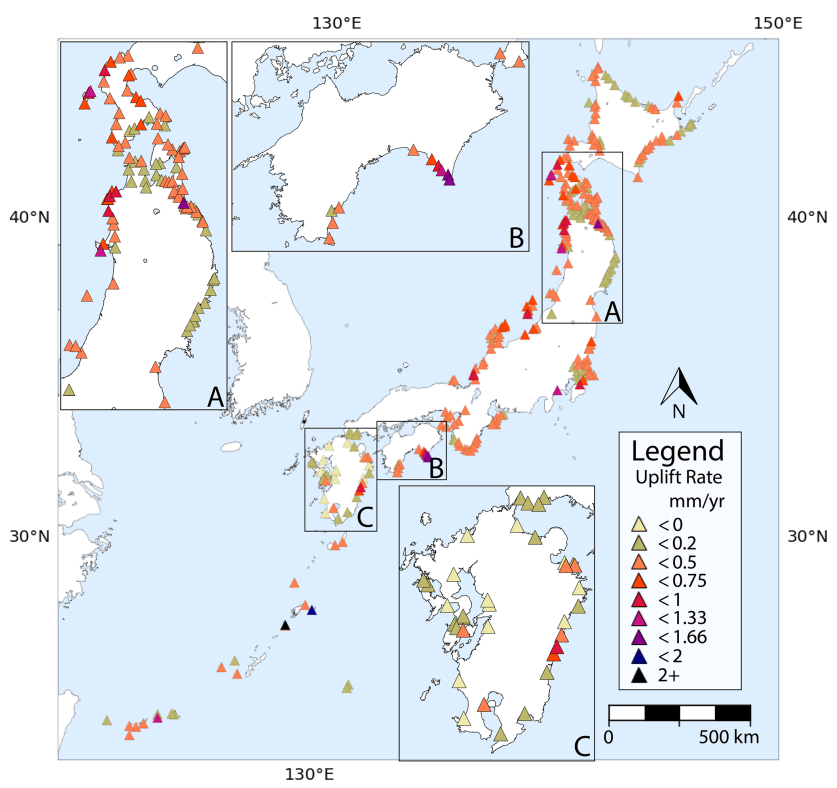

Figure 13. Sea-level proxies uplift rates throughout the Japanese archipelago. Rates of uplift (triangles) are indicated by color (see legend). Expanded views of rates of uplift in northern Honshu and Hokkaido (a), Shikoku (b), and Kyushu (c) are provided.

the Holocene (e.g., Maemoku, 1992; Hamanaka et al., 2015; Hongo and Kayanne, 2011) and on molluscs (e.g., Yokoyama et al., 2016) in the Ryukyu Islands. Largely, the same methods for examining MIS 5e sea-level proxies are also utilized, such as tephrochronology, stratigraphic correlation, and seismic crustal analysis (e.g., Moriwaki, 2006; Nagaoka et al., 2010; Shishikura et al., 2008).

\subsection{Uplift rates}

Uplift rates of sea-level proxies follow similar spatial distribution trends when compared to sea-level proxy elevations (Figs. 12,13). This can be seen in both Hokkaido and northern Honshu, where higher uplift rates align with higher elevation (Figs. 4, 5, 13a). Similarly, subsidence rates match sea-level proxies with negative elevations, which can be observed around Kyushu (Figs. 10, 13c). These uplift rates likely represent long-term crustal tectonic uplift rates (Okuno et al., 2014). The link between uplift rates and elevation of sea-level proxies highlights the major role that tectonic uplift plays in preserving sea-level proxies around Japan. Additionally, smaller regional uplift patterns can be observed through both uplift rates and elevations, such as on the southeastern tip of Shikoku (Fig. 13b) where both elevations and uplift rates increase moving south. Studies examining uplift in Japan generally focus on specific regions at a time (e.g., Tamura et al., 2010; Matsuura, 2015), though studies compiling and examining uplift rates throughout Japan also exist (Pedoja et al., 2014; Okuno et al., 2014).

\section{Data availability}

Data from this study are open access and available at the following link: https://doi.org/10.5281/zenodo.4294326 (Tam and Yokoyama, 2020). Data were exported from the WALIS database on 28 November 2020, and database descriptions can be found at the following link: https://doi.org/10.5281/zenodo.3961543 (Rovere et al., 2020). Further information about the database can be examined here: https://warmcoasts.eu/world-atlas.html (last access: 31 January 2021).

\section{Concluding remarks}

Sea-level proxies denoting MIS 5e have been abundantly observed and studied in Japan. Use of U-Th dating techniques in the coral-rich Ryukyu Islands has allowed for its terraces to be correlated to global MIS stages, and Japan's abundant tephra sources have likewise allowed for intra-country age constraints on stratigraphic layers and identified terraces. Though chronostratigraphic techniques in Japan are recognized as reliable and accurate, opportunities exist to constrain sea-level proxies more accurately and to cross-check ages for established chronohorizons by utilizing numerical age dating techniques. Several papers have validated the use of more precise numerical age dating techniques on sea-level proxies in Japan, with pIRIR OSL and cosmogenic nuclide dating techniques having been successfully used to date marine sediments and marine terraces. Future studies could benefit from more rigorous descriptions of sea-level proxy characteristics and measurement techniques utilized. Otherwise, studies of sea-level proxies from in and around Japan have created a large, predominantly reliable collection of MIS 5e sea-level proxies that can be utilized for future studies.

Supplement. The supplement related to this article is available online at: https://doi.org/10.5194/essd-13-1477-2021-supplement.

Author contributions. ET was the primary data compiler, analyst, and author of the paper. YY designed the research, oversaw the project, and contributed to the paper.

Competing interests. The authors declare that they have no conflict of interest.

Special issue statement. This article is part of the special issue "WALIS - the World Atlas of Last Interglacial Shorelines". It is not associated with a conference.

Acknowledgements. We would like to thank Alessio Rovere for inviting us to be a part of this project. Special thanks are due 
to Kai Leggett, who assisted with translation, literature compilation, and data uploading, and to Jorge Alberto Garcia Perez, Colm Murphy, and Jiwon Yeom for advising on data collection methods. This study was supported partially by the JSPS KAKENHI grant (JP20H00193). The data compiled for this study were uploaded into WALIS, a sea-level database interface developed by the ERC Starting Grant "WARMCOASTS" (ERC-StG-802414), in collaboration with PALSEA (PAGES/INQUA) working group. The database structure was designed by Alessio Rovere, Dierdre Ryan, Thomas Lorscheid, Andrea Dutton, Peter Chutcharavan, Dominik Brill, Nathan Jankowski, Daniela Mueller, Melanie Bartz, Evan Gowan, and Kim Cohen.

Financial support. This research has been supported by the Japan Society for the Promotion of Science (KAKENHI grant no. JP20H00193).

Review statement. This paper was edited by Colin V. MurrayWallace and reviewed by Thomas M. Cronin and Luigi Ferranti.

\section{References}

AIST (National Institute of Advanced Industrial Science and Technology): Research on an evaluation method for uplift and denudation rates on the Kamikita Plain, Aomori Prefecture, in: The 2016 Fiscal Year Project Report of Expenses for Commission of Safety Review for Geological Disposal of Radioactive Waste: Evaluation Methods toward Safety Review, Geological Information Section, AIST, Ibaraki, Japan, 2015 (in Japanese).

AIST (National Institute of Advanced Industrial Science and Technology): Research on an evaluation method for uplift and denudation rates, in: The 2017 Fiscal Year Project Report of Expenses for Commission of Safety Control for Nuclear Power Plant Facilities: Reconnaissance Investigation for Log-Term Prediction of Natural Disaster AIST, Ibaraki, Japan, 2016 (in Japanese).

Amano, H., Suzuki, S., Sato, M., and Yanagida, M.: A new method of terrace analysis to determine precise altitudes of former shoreline, Okayama University Earth Science Report, 25, 31-38, https://doi.org/10.18926/ESR/56694, 2018.

Ando, M., Kitamura, A., Tu, Y., Ohashi, Y., Imai, T., Nakamura, M., Ikuta, R., Miyairi, Y., Yokoyama, Y., and Shishikura, M.: Source of high tsunamis along the southernmost Ryukyu trench inferred from tsunami stratigraphy, Tectonophysics, 722, 265276, https://doi.org/10.1016/j.tecto.2017.11.007, 2018.

Anthony, E. J.: Beach Erosion, in: Encyclopedia of Coastal Science, edited by: Finkl, C. and Makowski, C., Springer, Netherlands, Dordrecht, 632-633, https://doi.org/10.1007/978-3-319-486574, 2005.

Anthony, E. J.: Shore processes and their palaeoenvironmental applications, First Edition, Elsevier, Amsterdam, the Netherlands, https://doi.org/10.1016/s1572-5480(08)00417-x, 2008.

Aoki, K.: Revised age and distribution of ca. $87 \mathrm{ka}$ Aso-4 tephra based on new evidence from the northwest Pacific Ocean, Quaternary International, 178, 100-118, https://doi.org/10.1016/j.quaint.2007.02.005, 2008.
Apel, E. V., Bürgmann, R., Steblov, G., Vasilenko, N., King, R., and Prytkov, A.: Independent active microplate tectonics of northeast Asia from GPS velocities and block modeling, Geophys. Res. Lett., 33, L11303, https://doi.org/10.1029/2006GL026077, 2006.

Arai, F., Machida, H., Okumura, K., Miyauchi, T., Soda, T., and Yamagata, K.: Catalog for late Quaternary marker-tephras in Japan II - Tephras occurring in the Northeast Honshu and Hokkaido, Geographical reports of Tokyo Metropolitan University, 21, $223-$ 250, 1986 (in Japanese).

Chappell, J.: Geology of coral terraces, Huon Peninsula, New Guinea: a study of Quaternary tectonic movements and sea-level changes, Geol. Soc. Am. Bull., $\quad 85, \quad 553-570, \quad$ https://doi.org/10.1130/00167606(1974)85\%3C553:GOCTHP\%3E2.0.CO;2, 1974.

Chappell, J., Ota, Y., and Berryman, K.: Late Quaternary coseismic uplift history of Huon Peninsula, Papua New Guinea, Quaternary Sci. Rev., 15, 7-22, https://doi.org/10.1016/02773791(95)00062-3, 1996.

Chida, N.: Geomorphic history and recent crustal movement of Oita coastal plain, east central Kyushu, Japan, Geogr. Rev. Japan, 47, 181-194, https://doi.org/10.4157/grj.47.181, 1974 (in Japanese).

Church, J. A., Gregory, J. M., Huybrechts, P., Kuhn, M., Lambeck, K., Nhuan, M. T., Qin, D., Woodworth, P. L., Anisimov, O. A., Bryan, F. O., Cazenave, A., Dixon, K. W., Fitzharris, B. B., Flato, G. M., Ganopolski, A., Gornitz, V., Lowe, J. A., Noda, A., Oberhuber, J. M., O’Farrell, S. P., Ohmura, A., Oppenheimer, M., Peltier, W. R., Raper, S. C. B., Ritz, C., Russell, G. L., Schlosser, E., Shum, C. K., Stocker, T. F., Stouffer, R. J., van de Wal, R. S. W., Voss, R., Wiebe, E. C., Wild, M., Wingham, D. J., and Zwally, H. J.: Changes in Sea Level, in Climate Change 2001: The Scientific Basis - Contribution of Working Group I to the Third Assessment Report of the Intergovernmental Panel on Climate Change, edited by: Houghton, J. T., Ding, Y., Griggs, D. J., Noguer, M., van der Linden, P. J., Dai, X., Maskell, K., and Johnson, C. A., 639-693, Cambridge University Press, Cambridge and New York, https://doi.org/10.1002/joc.763, 2001.

Dutton, A. and Lambeck, K.: Ice volume and sea level during the last interglacial, Science, 337, 216-219, https://doi.org/10.1126/science.1205749, 2012.

FAO: Patinopecten Yessoensis, Food and Agriculture Organization of the United Nations, FAO, Food and Agriculture Organization of the United Nations, available at: http://www.fao.org/fishery/ culturedspecies/Patinopecten_yessoensis/en, last access: 15 October 2020.

Frey, R. W., Howard, J. D. and Pryor, W. A.: Ophiomorpha: its morphologic, taxonomic, and environmental significance, Palaeogeography, Palaeoclimatology, Palaeoecology, 23, 199229, https://doi.org/10.1016/0031-0182(78)90094-9, 1978.

Fukuyo, N., Clark, G., Purcell, A., Parton, P., and Yokoyama, Y.: Holocene sea level reconstruction using lagoon specific local marine reservoir effect and geophysical modeling in Tongatapu, Kingdom of Tonga, Quaternary Sci. Rev., 244, 106464 , https://doi.org/10.1016/j.quascirev.2020.106464, 2020.

Ganzawa, Y. and Ike, M.: SAR-RTL dating of single grains of volcanic quartz from the late Pleistocene Toya Caldera, Quaternary Geochronology, 6, 42-49, https://doi.org/10.1016/j.quageo.2010.07.001, 2011.

Harris, J.: Pacific oyster, Crassostrea gigas (Thunberg, 1793), available at: http://depts.washington.edu/oldenlab/wordpress/ 
wp-content/uploads/2013/02/Crassostrea-gigas_Harris.pdf (last access: 10 October 2020), 2008.

Hamanaka, N., Kan, H., Nakashima, Y., Yokoyama, Y., Okamoto, T., Ohashi, T., Adachi, H., Matsuzaki, H., and Hori, N.: Holocene reef-growth dynamics on Kodakara Island $\left(29^{\circ} \mathrm{N}\right.$, $129^{\circ}$ E) in the Northwest Pacific, Geomorphology, 243, 27-39, https://doi.org/10.1016/j.geomorph.2015.04.011, 2015.

Hasegawa, T., Nakagawa, M., and Kishimoto, H.: The eruption history and silicic magma systems of caldera-forming eruptions in eastern Hokkaido, Japan, J. Mineral. Petrol. Sci., 107, 39-43, https://doi.org/10.2465/jmps.111020h, 2012.

Hataya, R. and Shirai, M.: Optically stimulated luminescence (OSL) dating of shallow marine sediments to develop an analysis method of late Quaternary geodynamics, Denryoku Chuo Kenkyusho Hokoku, 42, 347-359, https://doi.org/10.4116/jaqua.42.347, 2003.

Hayakawa, Y.: Mode of eruption and deposition of the Hachinohe phreatoplinian ash from the Towada volcano, Japan, Geographical Reports of Tokyo Metropolitan University, 25, 167-182, 1990.

Hayatsu, K., Arai, F., and Shirai, T.: Tephrochronological Study on "Middle Terrace" and "Ancient Dune" in the Takada Plain, Niigata Prefecture, Central Japan, J. Geogr., 91, 1-16, https://doi.org/10.5026/jgeography.91.1, 1982 (in Japanese).

Hijma, M. P., Engelhart, S. E., Törnqvist, T. E., Horton, B. P., Hu, P., and Hill, D. F.: A protocol for a geological sea-level database, in Handbook of Sea-level Research, 1st edn., edited by: Shennan, I., Long, A., and Horton, B., John Wiley \& Sons, West Sussex, UK, 536-553, https://doi.org/10.1002/9781118452547.ch34, 2015.

Hiroki, Y.: Quaternary crustal movements examined from facies distribution in the Atsumi and Hamana areas, central Japan, Sediment. Geol., 93, 223-235, https://doi.org/10.1016/00370738(94)90007-8, 1994.

Hongo, C. and Kayanne, H.: Key species of hermatypic coral for reef formation in the northwest Pacific during Holocene sea-level change, Mar. Geol., 279, 162-177, https://doi.org/10.1016/j.margeo.2010.10.023, 2011.

Hosono, T., Lopati, P., Makolo, F., and Kayanne, H.: Mass culturing of living sands (Baculogypsina sphaerulata) to protect island coasts against sea-level rise, J. Sea Res., 90, 121-126, https://doi.org/10.1016/j.seares.2014.03.007, 2014.

Hydrographic and Oceanographic Department of the Japan Coast Guard: Tide Prediction Map (All Japan), available at: https://www1.kaiho.mlit.go.jp/KANKYO/TIDE/tide_ pred/index_e.htm, last access: 22 September 2020.

Ikeda, Y.: Coastal terraces and their deformations in AmamiOshima, Ryukyu Islands, southern Japan, J. Geogr., 86, 383-389, https://doi.org/10.5026/jgeography.86.6_383, 1977 (in Japanese).

Ikeya, M. and Ohmura, K.: Comparison of ESR ages of corals from marine terraces with ${ }^{14} \mathrm{C}$ and ${ }^{230} \mathrm{Th} /{ }^{234} \mathrm{U}$ ages, Earth Planet. Sci. Lett., 65, 34-38, https://doi.org/10.1016/0012-821X(83)901875,1983 .

Inagaki, M. and Omura, A.: Uranium-series age of the highest marine terrace of the Upper Pleistocene on Kikai Island, Central Ryukyus, Japan, Quaternary Res., 45, 41-48, https://doi.org/10.4116/jaqua.45.41, 2006 (in Japanese).

Inoue, T., Shioya, F., Iwamoto, N., Amano, A., and Inouchi, Y.: Marine geology and geologic history of Miho Bay, Southwest Japan, since the Late Pleistocene based on seismic profiles, J. Geogr., 111, 255-268, https://doi.org/10.5575/geosoc.111.255, 2005 (in Japanese).

Ishii, K., Shimoyama, S., and Matsuda, T.: The former shoreline heights of the last interglacial time and the Holocene time in the Yukuhashi plain, North Kyushu, Japan, Science reports, Department of Earth and Planetary Science, Kyushu University 18 , 157-175, 1994.

Ito, $\mathrm{H}$.: Zircon U-Th-Pb dating using LA-ICP-MS: simultaneous $\mathrm{U}-\mathrm{Pb}$ and $\mathrm{U}-\mathrm{Th}$ dating on the $0.1 \mathrm{Ma}$ Toya Tephra, Japan, J. Volcanol. Geothermal Res., 289, 210-223, https://doi.org/10.1016/j.jvolgeores.2014.11.002, 2014.

Ito, K., Tamura, T., and Tsukamoto, S.: Post-IR IRSL dating of $\mathrm{K}$-feldspar from last interglacial marine terrace deposits on the Kamikita coastal plain, northeastern Japan, Geochronometria, 44, 352-365, https://doi.org/10.1515/geochr-2015-0077, 2017.

James, N. P., Mountjoy, E. W., and Omura, A.: An early Wisconsin reef terrace at Barbados, West Indies, and its climatic implications, Geol. Soc. Am. Bull., 82, 2011-2018, https://doi.org/10.1130/00167606(1971)82[2011:AEWRTA]2.0.CO;2, 1971.

Japanese Coral Reef Society, Ministry of the Environment: Coral reefs of Japan. Ministry of the Environment, Japanese Coral Reef Soc, Tokyo, Japan, available at: http://www.jcrs.jp/ old/english/publications/coralreefsofjapan_top.htm (last access: 29 March 2021), 2004.

Kaizuka, S.: Quaternary crustal movements in Kanto, Japan, J. Geogr., 96, 223-240, https://doi.org/10.5026/jgeography.96.4_223, 1987 (in Japanese).

Kamada, Y., and Niino, H.: Pleistocene Marine Deposit of the northern Coast of the Tachibana Bay, Nagasaki Prefecture, Science reports of the Faculty of Arts and Literature, Nagasaki University, 4, 83-91, 1955 (in Japanese).

Koba, M., Nakata, T., and Watabe, S.: Late Quaternary reef caps of Takara and Kodakara islands, Ryukyu archipelago, and sea-level changes of late Holocene, Earth Sci., 33, 173191, https://doi.org/10.15080/agcjchikyukagaku.33.4_173, 1979 (in Japanese).

Koike, K. and Machida, H.: Atlas of Quaternary Marine Terraces in the Japanese Islands, University of Tokyo Press, Tokyo, Japan, https://doi.org/10.4116/jaqua.30.175, 2001 (in Japanese).

Konishi, K., Omura, A., and Nakamichi, O.: Radiometric coral ages and sea level records from the late Quaternary reef complexes of the Ryukyu Island, in: Proceedings of the 2nd International Coral Reef Symposium, Brisbane, Australia, 22 June-2 July 1974, 595-614, 1974

Lisiecki, L. E. and Raymo, M. E: A Pliocene-Pleistocene stack of 57 globally distributed benthic $\delta^{18} \mathrm{O}$ records, Paleoceanography, 20, PA1003, https://doi.org/10.1029/2004PA001071, 2005.

Lorscheid, T. and Rovere, A.: The indicative meaning calculatorquantification of paleo sea-level relationships by using global wave and tide datasets, Open Geospatial Data Software and Standards, 4, 10, https://doi.org/10.1186/s40965-019-0069-8, 2019.

Machida, H.: Tephrochronology of coastal terraces and their tectonic deformation in South Kanto, J. Geogr., 82, 53-76, https://doi.org/10.5026/jgeography.82.2_53, 1973 (in Japanese).

Machida, H.: Pleistocene sea-level of south Kanto, Japan, analysed by tephrochronology, Royal Society of New Zealand, 13, 215222, 1975. 
Machida, H.: Volcanoes and tephras in the Japan area, Global Environmental Research - English Edition, 6, 19-28, 2002.

Machida, H. and Arai, F.: Daisen Kurayoshi pumice: stratigraphy, chronology, distribution and implication to Late Pleistocene events in central Japan, J. Geogr., 88, 313330, https://doi.org/10.5026/jgeography.88.5_313, 1979 (in Japanese).

Machida, H. and Arai, F.: Extensive ash falls in and around the Sea of Japan from large late Quaternary eruptions, J. Volcanol. Geoth. Res., 18, 151-164, https://doi.org/10.1016/03770273(83)90007-0, 1983.

Machida, H. and Arai, F.: Atlas of Tephra in and around Japan, University of Tokyo Press, Tokyo, Japan, 2003 (in Japanese).

Machida, H., Arai, F., Miyauchi, T., and Okumura, K.: Toya ash-A widespread late Quaternary timemarker in northern Japan, Quatern. Res., 26, 129-145, https://doi.org/10.4116/jaqua.26.2_129, 1987 (in Japanese).

Machida, H., Ota, Y., Kawana, T., Moriwaki, H., and Nagaoka, S.: Geography of Japan, Volume 7: Kyushu and the Southern Islands, University of Tokyo Press, Tokyo, Japan, 2001 (in Japanese).

Maemoku, H.: Holocene tectonic movements in the southern part of the outer zone of Southwest Japan, Quatern. Res., 31, 285-296, https://doi.org/10.4116/jaqua.31.285, 1992 (in Japanese).

Matsuura, T.: Late Quaternary uplift rate inferred from marine terraces, Muroto Peninsula, southwest Japan: Forearc deformation in an oblique subduction zone, Geomorphology, 234, 133-150, https://doi.org/10.1016/j.geomorph.2015.01.012, 2015.

Matsuura, T., Furusawa, A., and Saomoto, H.: Long-term and short-term vertical velocity profiles across the forearc in the NE Japan subduction zone, Quatern. Res., 71, 227-238, https://doi.org/10.1016/j.yqres.2008.12.005, 2009.

Matsuura, T., Kimura, H., Komatsubara, J., Goto, N., Yanagida, M., Ichikawa, K., and Furusawa, A.: Late Quaternary uplift rate inferred from marine terraces, Shimokita Peninsula, northeastern Japan: A preliminary investigation of the buried shoreline angle, Geomorphology, 209, 1-17, https://doi.org/10.1016/j.geomorph.2013.11.013, 2014.

Matsuura, T., Komatsubara, J., and Wu, C.: Accurate determination of the Pleistocene uplift rate of the NE Japan forearc from the buried MIS 5e marine terrace shoreline angle, Quatern. Sci. Rev., 212, 45-68, https://doi.org/10.1016/j.quascirev.2019.03.007, 2019.

Milne, G.: Sea Level, in Coastal Environments and Global Change, 1st edn., edited by: Masselink, G. and Gehrels, R., John Wiley \& Sons, West Sussex, UK, 28-51, https://doi.org/10.1002/9781119117261.ch2, 2014.

Mitsushio, T., Nishikawa, T., and Mimoto, K.: Upper Pliocene to Pleistocene System at the Nuno Cape and Ohki Areas, Ashizuri Region, West Coast of Tosa Bay, Research Reports of Kochi University, Natural Science, 38, 63-72, 1989 (in Japanese).

Miura, O.: Coastal terraces and rias along the Kesennuma Bay, Miyagi Prefecture, Annals of The Tohoku Geographical Association, 18, 116-122, https://doi.org/10.5190/tga1948.18.116, 1966 (in Japanese).

Miura, K. and Hayashi, M.: Quarternary Tephra Studies in the Chugoku and Shikoku Districts, Quaternary Res., 30, 339-351, https://doi.org/10.4116/jaqua.30.339, 1991.
Miyairi, Y., Yoshida, K., Miyazaki, Y., Matsuzaki, H., and Kaneoka, I.: Improved ${ }^{14} \mathrm{C}$ dating of a tephra layer (AT tephra, Japan) using AMS on selected organic fractions, Nucl. Instrum. Meth. B, 223, 555-559, https://doi.org/10.1016/j.nimb.2004.04.103, 2004.

Miyauchi, T.: Quaternary crustal movements estimated from deformed terraces and geologic structures of the Kamikita coastal plain, northeast Japan, Geogr. Rev. Jpn. A, 61, 404-422, 1985 (in Japanese).

Miyauchi, T.: Quaternary tectonic movements of the Kamikita coastal plain, northeast Japan, Geogr. Rev. Jpn. B, 60, 1-19, https://doi.org/10.4157/grj1984b.60.1, 1987.

Miyauchi, T.: Late Pleistocene marine terrace correlation and chronology in the northern Northeast Japan, Geographical Reports of Tokyo Metropolitan University, 23, 29-47, 1988.

Miyazaki, M. and Ishimura, D.: Re-examination of the Ages of the Last Interglacial Marine Terraces and Crustal Movements Since the Last Interglacial Period along the Northern Sanriku Coast Based on Tephrochronology, J. Geogr., 127, 735-757, https://doi.org/10.5026/jgeography.127.735, 2018.

Mizutani, T.: Longitudinal profile evolution of valleys on coastal terraces under the compound influence of eustasy, tectonism and marine erosion, Geomorphology, 17, 317-322, https://doi.org/10.1016/0169-555X(96)00013-X, 1996.

Moriwaki, H.: Holocene Marine-Terrace Chronology based on Kikai-Akahoya Tephra in Yakushima and Tanegashima Islands, south Japan, Kagoshima University Research Center for the Pacific Islands Occasional Papers, 46, 58-64, 2006 (in Japanese).

Muto, M.: Data on active faults in the Shima Peninsula, Active Fault Research, 7, 82-86, 1989.

Nagaoka, S., Nishiyama, K. I., and Inoue, Y.: Geologic and geomorphologic evolution of Miyazaki Plain in southern Japan during the past $2 \mathrm{Ma}$, based on the sea-level change and tectonics, J. Geogr., 119, 632-667, https://doi.org/10.5026/jgeography.119.632, 2010 (in Japanese).

Naito, H.: Terraces of the Noshiro Plain, Akita Prefecture, Northeast Japan, Quatern. Res., 16, 57-70, https://doi.org/10.4116/jaqua.16.57, 1977 (in Japanese).

Nakamori, T., Campbell, C. R., and Wallensky, E.: Living hermatypic coral assemblages at Huon Peninsula, Papua New Guinea, J. Geogr., 104, 743-757, https://doi.org/10.5026/jgeography.104.5_743, 1995 (in Japanese).

Nakanishi, R., Okamura, S., Yokoyama, Y., Miyairi, Y., Sagayama, T., and Ashi, J.: Holocene tsunami, storm, and relative sea level records obtained from the southern Hidaka coast, Hokkaido, Japan, Quatern. Sci. Rev., 250, 106678, https://doi.org/10.1016/j.quascirev.2020.106678, 2020.

Okumura, K.: Recurrence of large pyroclastic flows and innovation of volcanic activity in eastern Hokkaido, in: Kagoshima International Conference on Volcanoes, Kagoshima, Japan, 19-23 July 1988, 518-521, 1988.

Okumura, K. and Sangawa, A.: Age and distribution of Toya pyroclastic flow, Bulletin of the Volcanological Society of Japan, 29, 338, https://doi.org/10.5026/jgeography.127.191, 1984 (in Japanese).

Okuno, J. I., Nakada, M., Ishii, M., and Miura, H.: Vertical tectonic crustal movements along the Japanese coastlines inferred from late Quaternary and recent rel- 
ative sea-level changes, Quatern. Sci. Rev., 91, 42-61, https://doi.org/10.1016/j.quascirev.2014.03.010, 2014.

Omura, A., Iwata, H., Ota, Y., Koba, M., and Kawana, T.: ${ }^{230} \mathrm{Th} /{ }^{234} \mathrm{U}$ dates of late Pleistocene corals from Kita-and Minami-Daito Islands, Okinawa, Japan, J. Geogr., 100, 337350, https://doi.org/10.5026/jgeography.100.3_337, 1991 (in Japanese).

Omura, A., Kodama, K., Watanabe, M., Suzuki, A., and Ota, Y.: Tectonic history of Yonaguni Island, southwestern Ryukyus, Japan, deduced from coral reef terraces and uranium-series dates of Pleistocene corals, Quatern. Rese., 33, 213-231, https://doi.org/10.4116/jaqua.33.213, 1994 (in Japanese).

Omura, A., Sasaki, K., Terao, D., and Murakami, K.: A chronological and sedimentary study on the Pleistocene Series in Kikai Island, central Ryukyus, southwestern Japan, Quatern. Res., 39, 55-68, https://doi.org/10.4116/jaqua.39.55, 2000 (in Japanese).

Ota, Y.: Marine terraces and crustal movement in the western foot area of the Asahi Mountains, Northeast Japan, Science reports of the Yokohama National University - Section II, Biological and geological sciences, 18, 61-72, 1971 (in Japanese).

Ota, Y.: Marine terraces as reference surface in late Quaternary tectonics studies: Examples from the Pacific rim, Royal Society of New Zealand Bulletin, 24, 357-375, 1986.

Ota, Y. and Hirakawa, K.: Marine terraces and their deformation in Noto Peninsula, Japan sea side of central Japan, Geogr. Rev. Jpn., 52, 169-189, https://doi.org/10.4157/grj.52.169, 1979 (in Japanese).

Ota, Y. and Machida, H.: Quaternary sea-level changes in Japan, in: Sea-level Changes, edited by: Tooley, M. J. and Shennan, I., Basil Blackwell, Oxford, UK, 182-224, https://doi.org/10.1002/jqs.3390040110, 1987.

Ota, Y. and Omura, A.: Contrasting styles and rates of tectonic uplift of coral reef terraces in the Ryukyu and Daito Islands, southwestern Japan, Quatern. Int., 15, 17-29, https://doi.org/10.1016/1040-6182(92)90033-X, 1992.

Ota, Y. and Odagiri, S.: Age and deformation of marine terraces on the Ashizuri Peninsula and its vicinity, southwestern Japan, J. Geogr., 103, 243-267, https://doi.org/10.5026/jgeography.103.243, 1994 (in Japanese).

Ota, Y. and Omura, A.: Late Quaternary shorelines in the Japanese islands, Quatern. Res., 30, 175-186, https://doi.org/10.4116/jaqua.30.175, 1991.

Ota, Y., Matsushima, Y., and Moriwaki, H.: Atlas of Holocene sea level records in Japan, Japanese Working Group of the Project 61, Holocene Sea Level Project, IGCP, 195, 1981.

Ota, Y., Matsushima, Y., Umitsu, M., and Koike, K. (Eds.): Atlas of Late Quaternary sea level records in Japan, vol. 1, Review papers and Holocene, Japanese Working Group of IGCP Project 200, IGCP, 529 pp., 1987.

Otto-Bliesner, B. L., Marshall, S. J., Overpeck, J. T., Miller, G. $\mathrm{H}$., and $\mathrm{Hu}$, A.: Simulating Arctic climate warmth and icefield retreat in the last interglaciation, Science, 311, 1751-1753, https://doi.org/10.1126/science.1120808, 2006

Okumura, K.: Quaternary tephra studies in the Hokkaido district, northern Japan, Quatern. Res., 30, 379-390, https://doi.org/10.4116/jaqua.30.379, 1991 (in Japanese).

Okumura, K.: Tephrochronology, correlation, and deformation of marine terraces in eastern Hokkaido, Japan, Geographical Reports of Tokyo Metropolitan University, 31, 19-26, 1996.
Overpeck, J. T., Otto-Bliesner, B. L., Miller, G. H., Muhs, D. R., Alley, R. B. and Kiehl, J. T.: Paleoclimatic evidence for future ice-sheet instability and rapid sea-level rise, Science, 311, 17471750, https://doi.org/10.1126/science.1115159, 2006.

Paphia Undulata: https://www.sealifebase.se/summary/ Paphia-undulata.html, last access: 15 October 2020.

Pathansali, D.: Notes on the biology of the cockle, Anadara granosa L., Proceedings of the Indo-Pacific Fisheries Council, 11, 84-98, 1966.

Pedoja, K., Husson, L., Regard, V., Cobbold, P. R., Ostanciaux, E., Johnson, M. E., Kershaw, S., Saillard, M., Martinod, J., Furgerot, L., and Weill, P.: Relative sea-level fall since the last interglacial stage: are coasts uplifting worldwide?, Earth-Sci. Rev., 108, 1$15,2011$.

Pedoja, K., Husson, L., Johnson, M.E., Melnick, D., Witt, C., Pochat, S., Nexer, M., Delcaillau, B., Pinegina, T., Poprawski, Y., and Authemayou, C.: Coastal staircase sequences reflecting sea-level oscillations and tectonic uplift during the Quaternary and Neogene, Earth-Sci. Rev., 132, 13-38, https://doi.org/10.1016/j.earscirev.2014.01.007, 2014.

Pirazzoli, P. A.: Marine terraces, in: Encyclopedia of Coastal Science, edited by: Finkl, C. and Makowski, C., Springer, Netherlands, Dordrecht, 632-633, https://doi.org/10.1007/978-3-31948657-4, 2005.

Rohling, E. J., Grant, K., Hemleben, C. H., Siddall, M., Hoogakker, B. A. A., Bolshaw, M., and Kucera, M.: High rates of sea-level rise during the last interglacial period, Nat. Geosci., 1, 38-42, https://doi.org/10.1038/ngeo.2007.28, 2008.

Rovere, A., Raymo, M. E., Vacchi, M., Lorscheid, T., Stocchi, P., Gomez-Pujol, L., Harris, D. L., Casella, E., O'Leary, M. J., and Hearty, P. J.: The analysis of Last Interglacial (MIS 5e) relative sea-level indicators: Reconstructing sealevel in a warmer world, Earth-Sci. Rev., 159, 404-427, https://doi.org/10.1016/j.earscirev.2016.06.006, 2016.

Rovere, A., Ryan, D., Murray-Wallace, C., Simms, A., Vacchi, M., Dutton, A., Lorscheid, T., Chutcharavan, P., Brill, D., Bartz, M., Jankowski, N., Mueller, D., Cohen, K., and Gowan, E.: Descriptions of database fields for the World Atlas of Last Interglacial Shorelines (WALIS), Zenodo, https://doi.org/10.5281/zenodo.3961544, 2020.

Rahmstorf, S.: A semi-empirical approach to projecting future sea-level rise, Science, 315, 368-370, https://doi.org/10.1126/science.1135456, 2007.

Sakaguchi, Y.: The crustal movement of Hokkaido in the latest geologic age, Geogr. Rev. Jpn., 32, 401-431, https://doi.org/10.4157/grj.32.401, 1959 (in Japanese).

Sasaki, K., Omura, A., Murakami, K., Sagawa, N., and Nakamori, T.: Interstadial coral reef terraces and relative sea-level changes during marine oxygen isotope stages 3-4, Kikai Island, central Ryukyus, Japan, Quatern. Int., 120, 51-64, https://doi.org/10.1016/j.quaint.2004.01.006, 2004.

Shennan, I.: Interpretation of Flandrian sea-level data from the Fenland, England, P. Geologist Assoc., 93, 53-63, https://doi.org/10.1016/S0016-7878(82)80032-1, 1982.

Shimoyama, S., Kinoshita, H., Miyahara, M., Tanaka, Y., Ichihara, T., and Takemura, K.: Mode of vertical crustal movements during the Late Quaternary in Kyushu, Japan, deduced from heights of ancient shorelines, Tectonophysics, 302, 9-22, https://doi.org/10.1016/S0040-1951(98)00280-7, 1999. 
Shishikura, M., Echigo, T., Maemoku, H., and Ishiyama, T.: Height and ages of uplifted sessile assemblage distributed along the southern coast of the Kii Peninsula, south-central JapanReconstruction of multi-segment earthquake history along the Nankai Trough, Ann. Rep. Active Fault and Paleoearthquake Res., 8, 267-280, 2008 (in Japanese).

Stirling, C. H., Esat, T. M., McCulloch, M. T., and Lambeck, K.: High-precision U-series dating of corals from Western Australia and implications for the timing and duration of the Last Interglacial, Earth Planet. Sci. Lett., 135, 115-130, https://doi.org/10.1016/0012-821X(95)00152-3, 1995.

Stirling, C. H., Esat, T. M., Lambeck, K., and McCulloch, M. T.: Timing and duration of the Last Interglacial: evidence for a restricted interval of widespread coral reef growth, Earth Planet. Sci. Lett., 160, 745-762, https://doi.org/10.1016/S0012821X(98)00125-3, 1998.

Sugihara, S.: Geomorphological developments of the western Shimosa upland in Chiba Prefecture, Japan, Geogr. Rev. Jpn., 43, 703-718, https://doi.org/10.4157/grj.43.703, 1970 (in Japanese).

Suzuki, T.: Geomorphic development of the late Pleistocene terraces and buried valleys in southern Joban coastal region, north Kanto, Japan, Geogr. Rev. Jpn. A, 62, 475-494, 1989 (in Japanese).

Suzuki, T.: Stratigraphy of tephra layers from the latter half of middle Pleistocene to late Pleistocene in the Chubu-Kanto area, central Japan, Geographical Reports, Tokyo Metropolitan University, 27, 29-53, 1992.

Suzuki, T., Obara, M., Aoki, T., Murata, M., Kawashima, S., Kawai, M., Nakayama, T., and Tokizane, K, Identification of Lower Pleistocene tephras under Tokyo and reconstruction of Quaternary crustal movements, Kanto Tectonic Basin, central Japan, Quatern. Int., 246, 247-259, 2011.

Taira, A.: Tectonic evolution of the Japanese island arc system, Ann. Rev. Earth Planet. Sci., 29, 109-134, https://doi.org/10.1146/annurev.earth.29.1.109, 2001.

Taira, A., Ohara, Y., Wallis, S. R., Ishiwatari, A., and Iryu, Y.: Geological evolution of Japan: an overview, in: The Geology of Japan, edited by: Moreno, T., Wallis, S. R., Kojima, T., and Gibbons, W., The Geological Society, Bath, UK, 24 pp., https://doi.org/10.1144/GOJ.1, 2016.

Takarada, S. and Hoshizumi, H.: Distribution and eruptive volume of Aso-4 pyroclastic density current and tephra fall deposits, Japan: an M8 super-eruption, Front. Earth Sci., 8, 170 pp., https://doi.org/10.3389/feart.2020.00170, 2020.

Tam, E. and Yokoyama, Y.: Database of Last Interglacial Sea-level Proxies in and around Japan [Data set], Zenodo, https://doi.org/10.5281/zenodo.4294326, 2020.

Tamura, T., Murakami, F., and Watanabe, K.: Holocene beach deposits for assessing coastal uplift of the northeastern Boso Peninsula, Pacific coast of Japan, Quatern. Res., 74, 227-234, https://doi.org/10.1016/j.yqres.2010.07.009, 2010.

Tanaka, K., Hataya, R., Spooner, N. A., Questiaux, D. G., Saito, Y., and Hashimoto, T.: Dating of marine terrace sediments by ESR, TL and OSL methods and their applicabilities, Quatern. Sci. Rev., 16, 257-264, https://doi.org/10.1016/S02773791(96)00092-3, 1997.

Thiel, C., Tsukamoto, S., Tokuyasu, K., Buylaert, J. P., Murray, A. S., Tanaka, K., and Shirai, M.: Testing the application of quartz and feldspar luminescence dating to MIS 5
Japanese marine deposits, Quatern. Geochronol., 29, 16-29, https://doi.org/10.1016/j.quageo.2015.05.008, 2015.

Thompson, W. G., Curran, H. A., Wilson, M. A., and White, B.: Sea-level oscillations during the last interglacial highstand recorded by Bahamas corals, Nat. Geosci., 4, 684-687, https://doi.org/10.1038/ngeo1253, 2011.

Toma, T.: Tephrochronological Considerations on Emergence of the Shimosueyoshi Surface in Yokohama and its Surroundings, Japan, Quatern. Res., 13, 199-215, https://doi.org/10.4116/jaqua.13.199, 1974 (in Japanese).

Toyokura, I., Ohmura, K., Arai, F., Machida, H., Takase, N., Nakadaira, K. and Ito, T.: Identification of the Sambe Kisuki tephra found in marine terrace deposits along coastal areas of Hokuriku district, and its implications, Quatern. Res., 30, 79-90, https://doi.org/10.4116/jaqua.30.79, 1991 (in Japanese).

Tsukamoto, S., Duller, G. A. T., Wintle, A. G., and Frechen, M.: Optical dating of a Japanese marker tephra using plagioclase, Quatern. Geochronol., 5, 274-278, https://doi.org/10.1016/j.quageo.2009.02.002, 2010.

Umitsu, M.: Holocene sea-level changes and coastal evolution in Japan, Quatern. Res., 30, 87-196, https://doi.org/10.4116/jaqua.30.187, 1991.

Van de Plassche, O.: Sea-level Research: A Manual for the Collection and Evaluation of Data: a Manual for the Collection and Evaluation of Data, Springer, Amsterdam, the Netherlands, 1986.

Watanabe, M. and Une H.: Active Faulting and Mountain Building in the Eastern Marginal Area of the Niigata Plain, Central Japan, Geogr. Rev. Jpn., 58, 536-547, https://doi.org/10.4157/grj1984a.58.8_536, 1985 (in Japanese).

Watanabe, M., Nakata, T., and Suzuki, Y.: Active reverse faulting deduced from flexural deformation of marine terraces around southern area of the Shimokita Peninsula, northeast Japan, Active Fault Res., 29, 15-23, https://doi.org/10.11462/afr1985.2008.29_15, 2008 (in Japanese).

Yamamoto, H., Nakagawa, T., and Arai, F.: Marine terraces and tectonic uplift along the Echizen coast, Fukui prefecture, central Japan, Quatern. Res., 35, 75-85, https://doi.org/10.4116/jaqua.35.75, 1996 (in Japanese).

Yokoyama, Y. and Esat, T. M.: Global climate and sea level: Enduring variability and rapid fluctuations over the past 150,000 years, Oceanography, 24, 54-69, 2011.

Yokoyama, Y., Esat, T. M., and Lambeck, K.: Last glacial sealevel change deduced from uplifted coral terraces of Huon Peninsula, Papua New Guinea, Quatern. Int., 83, 275-283, https://doi.org/10.1016/S1040-6182(01)00045-3, 2001a.

Yokoyama, Y., Esat, T. M., and Lambeck, K.: Coupled climate and sea-level changes deduced from Huon Peninsula coral terraces of the last ice age, Earth Planet. Sc. Lett., 193, 579-587, https://doi.org/10.1016/S0012-821X(01)00515-5, $2001 \mathrm{~b}$.

Yokoyama, Y. and Esat, T.: Coral Reefs, in: Handbook of Sea-level Research, 1st Edn., edited by: Shennan, I., Long, A., and Horton, B., John Wiley \& Sons, West Sussex, UK, 104-124, 2015.

Yokoyama, Y., Nagano, G., Nakamura, A., Maemoku, H., Miyairi, Y., and Matsuzaki, H.: Uplift rates of the marine terraces in the south coast of Japan deduced from in situ cosmogenic ${ }^{10} \mathrm{Be}$ and ${ }^{26}$ Al, AGU Fall Meeting, San Fransisco, USA, 14-18 December 2015, T41B-2895, 2015. 
Yokoyama, Y., Maeda, Y., Okuno, J. I., Miyairi, Y., and Kosuge, T.: Holocene Antarctic melting and lithospheric uplift history of the southern Okinawa trough inferred from mid-to late-Holocene sea level in Iriomote Island, Ryukyu, Japan, Quatern. Int., 397, 342-348, https://doi.org/10.1016/j.quaint.2015.03.030, 2016.

Yokoyama, Y., Purcell, A., and Ishiwa, T.: Gauging Quaternary Sea Level Changes Through Scientific Ocean Drilling, Oceanography, 32, 64-71, https://doi.org/10.5670/oceanog.2019.121, 2019a.

Yokoyama, Y., Yamane, M., Nakamura, A., Miyairi, Y., Horiuchi, K., Aze, T., Matsuzaki, H., Shirahama, Y., and Ando, Y.: In-situ and meteoric ${ }^{10} \mathrm{Be}$ and ${ }^{26} \mathrm{Al}$ measurements: Improved preparation and application at the University of Tokyo, Nuclear Instruments and Methods in Physics Research Section B: Beam Interactions with Materials and Atoms, 455, 260-264. https://doi.org/10.1016/j.nimb.2019.01.026, 2019b.
Yonekura, N.: Geomorphic development and mode of crustal movement on the south coast of the Kii peninsula, southwestern Japan, J. Geogr., 77, 1-23, https://doi.org/10.5026/jgeography.77.1, 1968 (in Japanese).

Yonekura, N., Kaizuka S., Nogami, M., and Chinzei, K., Geography of Japan Volume 1: Overview, University of Tokyo Press, Tokyo, Japan, 2001 (in Japanese).

Yoshikawa, T., Kaizuka, S., and Ota, Y.: Mode of crustal movement in the late quaternary on the southeast coast of Shikoku, southwestern Japan, Geogr. Rev. Jpn., 37, 627-648, https://doi.org/10.4157/grj.37.627, 1964 (in Japanese).

Yoshiyama, A.: Late Quaternary Crustal Movement around the Hidaka Mountains, Hokkaido, Japan, Quatern. Res., 28, 369-387, https://doi.org/10.4116/jaqua.28.369, 1990. 